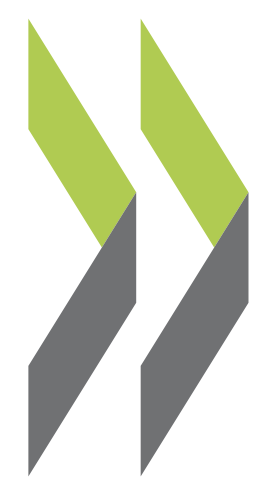

OECD Social, Employment and Migration Working Papers No. 215

\title{
How demanding are activation requirements for jobseekers
}

Herwig Immervoll, Carlo Knotz 
DIRECTORATE FOR EMPLOYMENT, LABOUR AND SOCIAL AFFAIRS

HOW DEMANDING ARE ACTIVATION REQUIREMENTS FOR JOBSEEKERS?

New evidence on activity-related eligibility criteria for unemployment and social assistance benefits

OECD SOCIAL, EMPLOYMENT AND MIGRATION WORKING PAPERS No. 215

JEL codes: I38, J08, J68, J65

For Further information contact:

Herwig Immervoll (Herwig.Immervoll@oecd.org) and Carlo Knotz (cknotz@bigsss -

bremen.de)

JT03434525 


\title{
OECD Social, Employment and Migration Working Papers
}

\author{
www.oecd.org/els/workingpapers
}

OECD Working Papers should not be reported as representing the official views of the OECD or of its member countries. The opinions expressed and arguments employed are those of the author(s).

Working Papers describe preliminary results or research in progress by the author(s) and are published to stimulate discussion on a broad range of issues on which the OECD works. Comments on Working Papers are welcomed, and may be sent to els.contact@oecd.org.

This series is designed to make available to a wider readership selected labour market, social policy and migration studies prepared for use within the OECD. Authorship is usually collective, but principal writers are named. The papers are generally available only in their original language - English or French - with a summary in the other.

This document and any map included herein are without prejudice to the status of or sovereignty over any territory, to the delimitation of international frontiers and boundaries and to the name of any territory, city or area.

The Republic of Cyprus is recognised by all members of the United Nations with the exception of Turkey. The information in this document relates to the area under the effective control of the Government of the Republic of Cyprus.

(C) OECD 2018

You can copy, download or print OECD content for your own use, and you can include excerpts from OECD publications, databases and multimedia products in your own documents, presentations, blogs, websites and teaching materials, provided that suitable acknowledgment of OECD as source and copyright owner is given. All requests for commercial use and translation rights should be submitted to rights@oecd.org. 


\section{Acknowledgements}

This document was produced with the financial assistance of the European Union Programme for Employment and Social Innovation "EaSI" (2014-2020). ECOECD grant agreement: VS/2015/0427 (DI150030).

This paper adapts and extends policy questionnaires from two earlier OECD studies. The authors thank Kristine Langenbucher for making the earlier questionnaire responses available and for providing generous and insightful advice. Authors gratefully acknowledge questionnaire responses received from OECD and EU countries, as well as comments on earlier drafts from delegates to the OECD Working Party on Social Policy, delegates to the Indicator Sub-group of the EU Social Protection Committee, and colleagues at the OECD. The opinions expressed and arguments employed herein are those of the authors and do not necessarily reflect the official views of the OECD member countries or of the European Union.

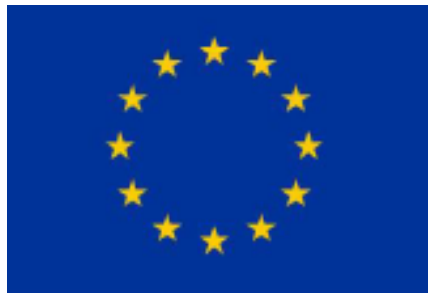

This project is co-funded by the European Union 


\section{Abstract}

This paper presents new information on activity-related eligibility criteria for unemployment and related benefits in OECD- and EU-countries in 2017, comparing the strictness of "demanding" elements built into unemployment benefits across countries and over time. Eligibility criteria for unemployment benefits determine what claimants need to do to successfully claim benefits initially or to continue receiving them. Benefit systems feature specific rules that define the type of job offers that claimants need to accept, requirements for reporting on the outcomes of independent job-search efforts, obligations to participate in active labour market programmes, as well as sanctions for failing to meet these requirements. Such rules aim to strengthen incentives to look for, prepare for, and accept employment. They may also be used as a targeting device to reduce demands on benefit systems, and on associated employment services. While this may serve to limit support to genuine jobseekers, strict requirements can also exclude some intended recipients from financial and re-employment support, e.g., by discouraging them from applying. This paper presents detailed information on policy rules in 2017, summarises them into an overall policy indicator of eligibility strictness, and gauges recent policy trends by documenting changes in the strictness measures. A novelty is the inclusion of lower-tier unemployment or social assistance benefits in the compilation of policy rules. Results document a large number of reforms enacted after the Great Recession and suggest a slight convergence of policy rules across countries even though overall measures of the strictness of activity-related eligibility criteria have remained broadly unchanged during the recent past. In countries with multiple layers of support for the unemployed, availability requirements tend to be more demanding for lower-tier assistance benefits, while sanction rules tend to be more stringent for first-tier programmes. 


\section{Resume}

Ce document présente de nouvelles informations sur les critères d'admissibilité liés au chômage et aux prestations connexes dans les pays de l'OCDE et de l'UE en 2017, comparant la rigueur des éléments "exigeants» basés sur les prestations de chômage dans les différents pays et dans le temps. Les critères de perception des prestations doivent être déterminés en premier lieu. Les systèmes de prestations comportent des règles spécifiques qui définissent le type d'exigences d'emploi à accepter, les exigences de déclaration des résultats des efforts indépendants de recherche d'emploi, les obligations de participer à des programmes actifs du marché du travail et les pénalités pour non-respect de ces exigences. Ces règles visent à renforcer les incitations à rechercher, préparer et accepter un emploi. Ils peuvent également être utilisés comme agents de ciblage pour réduire les demandes de prestations et sur les services d'emploi. Bien que cela puisse limiter le soutien aux demandeurs d'emploi réels, des exigences strictes peuvent également exclure certaines des cibles du soutien financier et du réemploi, par exemple en les décourageant de postuler. Ce document présente des informations détaillées sur les règles de politique en 2017 , les résume en un indicateur de politique générale d'éligibilité et de rigueur. Une nouveauté est l'inclusion des prestations d'aide sociale ou de palier inférieur dans la compilation des règles de politique. Résumé: un grand nombre de réformes dans le contexte d'un grand nombre de pays dans le passé Dans les pays avec plusieurs niveaux de soutien pour les chômeurs, il est nécessaire de fournir plus strictes pour les programmes de premier niveau. 


\section{Table of contents}

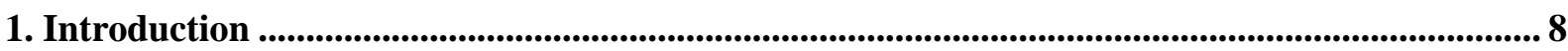

2. The design of unemployment benefits and the role of eligibility criteria and early

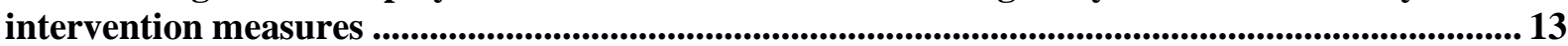

3. Strictness of eligibility criteria: A policy indicator for monitoring and benchmarking legal provisions................................................................................................................................................... 21

4. Eligibility criteria for $1^{\text {st }}$-tier unemployment benefits: Results for 2017 and recent changes..................................................................................................................................................................... 29

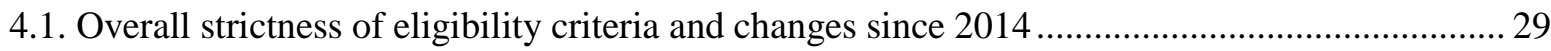

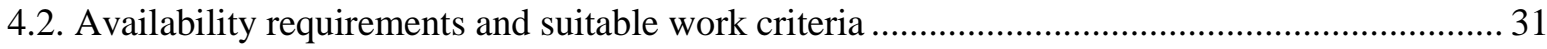

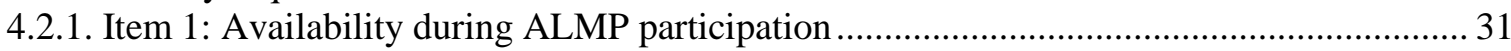

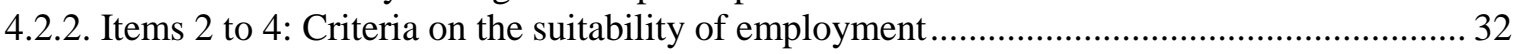

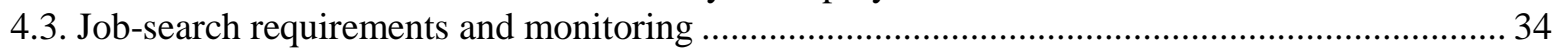

4.3.1. Memorandum item: Registration procedures, contact with employment service

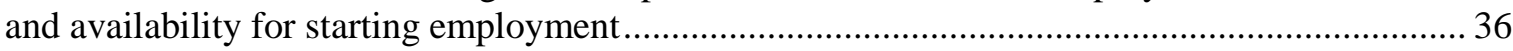

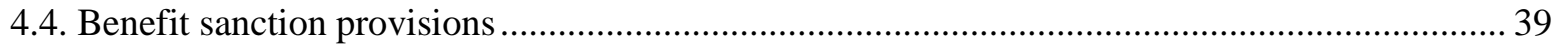

4.4.1. Item 7: Sanctions for voluntary resignation from employment ............................................ 40

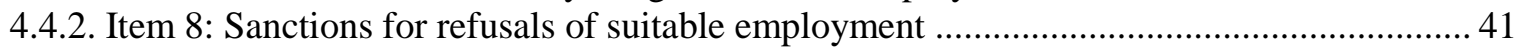

4.4.3. Item 9: Sanctions for repeated refusals of suitable employment ............................................. 41

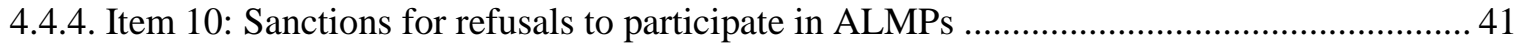

4.4.5. Item 11: Sanctions for repeated refusals to participate in ALMPs ......................................... 41

5. Eligibility conditions for lower-tier benefit programmes................................................................43

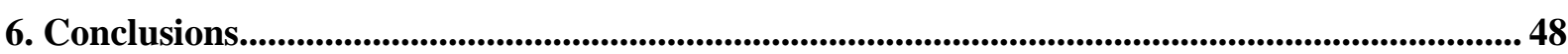

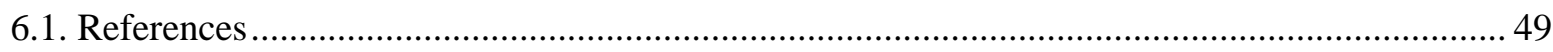

Tables

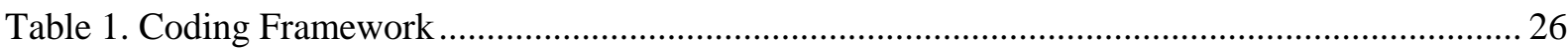

Table 2. Overall strictness indicators: Weighting of individual items ................................................ 28

Table 3. Unemployment benefit registration procedure and application routes, 2017 ........................ 38

Table 4. Scope of the eligibility questionnaires: $1^{\text {st }}-$ tier and lower-tier benefit programmes ............. 45

Figures

Figure 1. A small increase in the strictness of activity-related eligibility criteria for $1^{\text {st }}$-tier programmes and a slight recent convergence across countries ................................................ 1

Figure 2. Share of countries with different "activating" elements built into benefit eligibility conditions. 


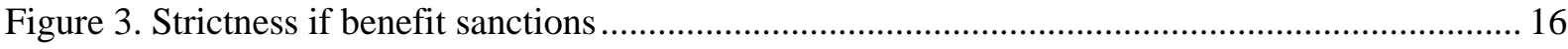

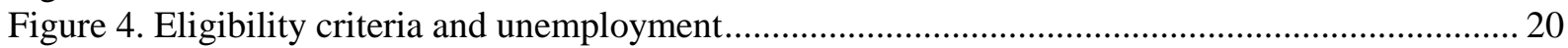

Figure 5. Benefits eligibility criteria: Overall strictness indicator for $1^{\text {st }}$ tier benefits ......................... 30

Figure 6. Availability requirements and suitable work criteria, 2017 ............................................... 31

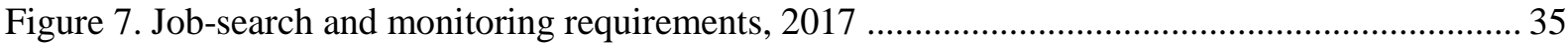

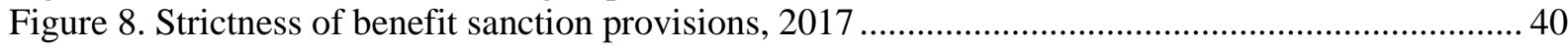

gure 9. Strictness of eligibility criteria compared across benefit programmes, 2017 ........................... 47

Boxes

Box 1. Have eligibility criteria become tighter over the last decades? ............................................. 15

Box 2. Association between labour-market conditions and eligibility criteria..................................... 19

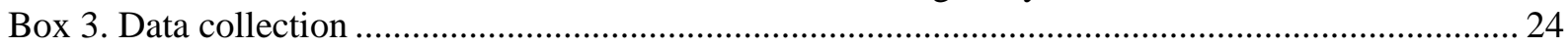




\section{Introduction}

1. As a central part of social security systems, unemployment benefits provide income support for unemployed individuals and their families, and enable them to devote time to finding suitable employment. However, a common concern related to benefit payments tied to joblessness is that they may erode job-search incentives, and that claimants may rely on government support for longer than is desirable or necessary. Such an outcome would create costs for taxpayers and for the unemployed alike. For instance, there is rich and consistent evidence that longer out-of-work spells reduce reemployment chances and have substantial adverse effects on personal finances and on physical and mental health (Ellwood, 1982; Graetz, 1993; Kletzer and Fairlie, 1999; Arulampalam, 2001; Thomas et al., 2004; Gregg and Tominey, 2005; Layard et al., 2005; Mroz and Savage, 2006; OECD, 2008a; Bell and Blanchflower, 2009; Sullivan and von Wachter, 2009; Oreopoulos et al., 2012).

2. But unemployment benefits are not available unconditionally. Instead, a range of provisions tie benefit receipt to past or current behaviour of benefit claimants. These conditions are a central design feature of "rights and responsibilities" approaches and of activation strategies that link support to individuals' own effort to re-establish selfsufficiency. Job-search and reporting requirements, participation in active labour market programmes (ALMPs) or conditions regarding the availability for work, may counteract disincentives resulting from out-of-work benefits to some extent, e.g. if they successfully convince benefit claimants to start looking for work more quickly, to search for employment more intensively, or to extend efforts to a wider range of potential employment opportunities. Available meta-evaluations suggest that job-search assistance services and benefit sanctions are effective in yielding positive employment effects, especially if job loss has been relatively recent (Kluve, 2010; Card et al., 2010; Card et al., 2015). However, there is no consistent evidence that countries use strict eligibility criteria to offset disincentives created by generous replacement rates (e.g., Langenbucher, 2015; Table 2).

3. But activity-related eligibility conditions can also function as a targeting mechanism, and these may be desirable even if they have no effect at all on the jobsearch behaviour of existing benefit claimants. By excluding some potential claimants from benefit payments, conditions act as a screening device. If screening works as intended, it can enable governments to provide more targeted (and potentially more generous) income and employment support to genuine and active jobseekers. Yet, as with any targeting device, activity-related eligibility rules give rise to possible tradeoffs. On the one hand, they should be sufficiently strict to minimise support payments resulting from claims that are considered illegitimate or unnecessary. On the other hand, they should not withhold adequate support from intended recipients.

4. For a number of reasons, the terms of such trade-offs are receiving renewed attention. On-going and anticipated labour-market transformations and new forms of work, also associated with digitalisation, may require revising eligibility conditions that 
were designed around relatively stable employment and traditional employer-employee contracts (OECD, 2017, 2018a). These relatively recent developments add to longerrunning challenges of falling benefit coverage (OECD, 2018b). For instance, declining shares of jobseekers receiving unemployment benefits have been identified as one of the factors that have made government redistribution less effective at stemming longer-term trends of rising income inequality (OECD, 2011; Immervoll and Richardson, 2011, Causa et al., 2017).

5. This paper presents new comparative data on the strictness of unemployment benefit eligibility conditions (availability requirements, job-search conditions and sanctions) across countries. Building on earlier OECD studies (Langenbucher, 2015, Venn, 2012) and contributing to a growing body of research on the "demanding" elements of unemployment benefits, it compiles rich data on countries' legal rules regarding job availability requirements and suitable-work criteria, job-search requirements and monitoring, and sanctions for noncompliance in around 40 OECD and EU countries. Updating earlier compilations of policy rules, and creating long time series of policy information across countries is important for two reasons. First, it permits monitoring trends in policy changes and "benchmarking" rights-and-responsibilities approaches across countries, and examining how these are associated with other policy choices and with labour-market conditions. Second, a long series of comparative policy indicators can contribute to our understanding of how policy configurations shape social and labour-market outcomes, providing a valuable complement to micro-based studies that tend to focus on individual countries at a given time.

6. In addition to updating results, the paper expands on previous studies in two respects. First, its scope is no longer restricted to the main first-tier unemployment benefit programme (often an insurance benefit), but also includes eligibility criteria for lower-tier unemployment or social assistance programmes, which have tended to become more common across countries. Second, the paper compiles additional information on the interactions between benefit claimants on one hand, and employment services and benefit administrations on the other. These additional aspects, including how unemployed workers apply for benefits and register for placement, are not commonly considered eligibility criteria. But they nonetheless shape the accessibility of benefits and play an important part in countries' labour-market activation strategies (OECD, 2015).

7. The results complement existing outcome and policy indicators on the generosity and accessibility of out-of-work benefits, such as trends in benefit recipient numbers (www.oecd.org/social/recipients.htm), net replacement rates and contribution or employment requirements (www.oecd.org/social/benefits-and-wages.htm). The resulting system of indicators is intended to support monitoring and benchmarking policy configurations across countries and over time. As policy indicators, the strictness measures presented here, as well as the underlying policy information, relate to the strictness of statutory rules, and not to the strictness of enforcement practice. Enforcement can vary even between countries with the same or very similar rules, between different time periods with similar statutory rules, as well as between different claimant groups in a given country or and year. Collecting information on enforcement practices, e.g., in the form of sanction statistics, is an important topic for future comparative work. There are nevertheless good reasons to consider statutory rules in isolation. First, statutory rules and enforcement in practice are distinct phenomena that warrant measurement on their own, while an aggregate indicator that measures statutes and enforcement together arguably obscures more than it reveals (for instance, the number of sanctions depend on both policy rules and claimant characteristics/behaviour). 
Second, deviations, tensions and possible links between statutory rules and their enforcement are interesting phenomena in and of themselves, which can only be studied empirically when separate measurements are available.

8. The present compilation of 2017 policy rules suggests that overall strictness for first-tier programmes has often remained broadly stable since 2011. Reforms were introduced in a number of countries, however, including in some where unemployment remained high during much of the post-crisis years (e.g., Finland, France, Italy, or Ireland). Figure 1 shows this graphically, by plotting country averages of overall "strictness" scores, and of its three components. The overall strictness measure of eligibility requirements, which ranges from 1 (least strict) to 5 (most strict), increased very slightly between 2011 and 2017 (Panel A). The increase is driven by a modest tightening across all three components of the overall score: Availability requirements, job-search conditions, and sanctioning rules. Across countries, the data indicate a very small degree of convergence, with strictness scores becoming slightly more similar over the past three years (Panel B). This follows some divergence during the earlier post-crisis period (2011-2014), although these earlier changes have also been quantitatively small. 
Figure 1. A small increase in the strictness of activity-related eligibility criteria for $1^{\text {st }}$-tier programmes and a slight recent convergence across countries

Scored from 1 (most lenient) to 5 (most strict)

Panel A: Overall score and sub-components, 2011-2017, levels

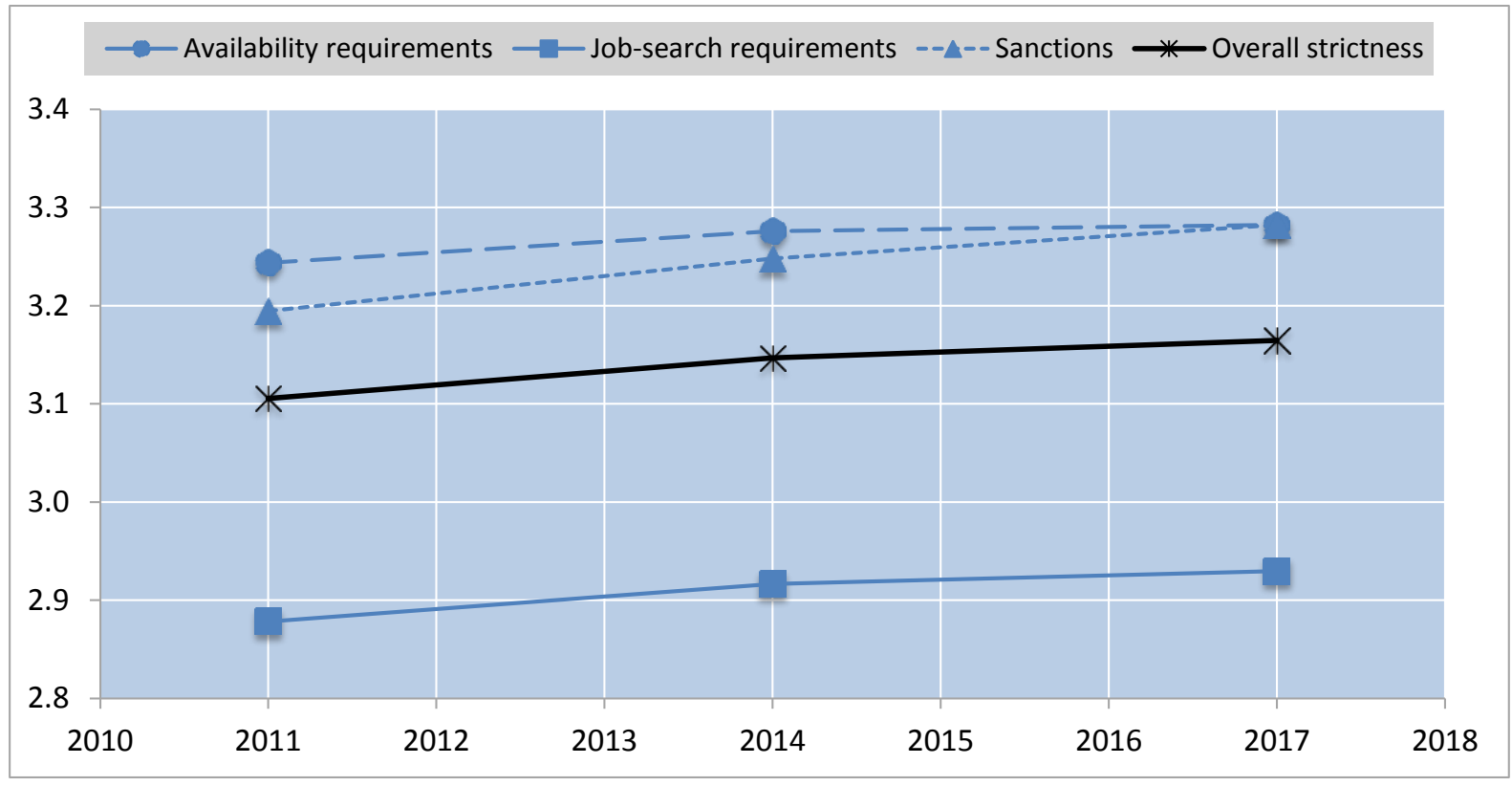

Panel B: Overall score and sub-components, 2011-2017, standard deviation

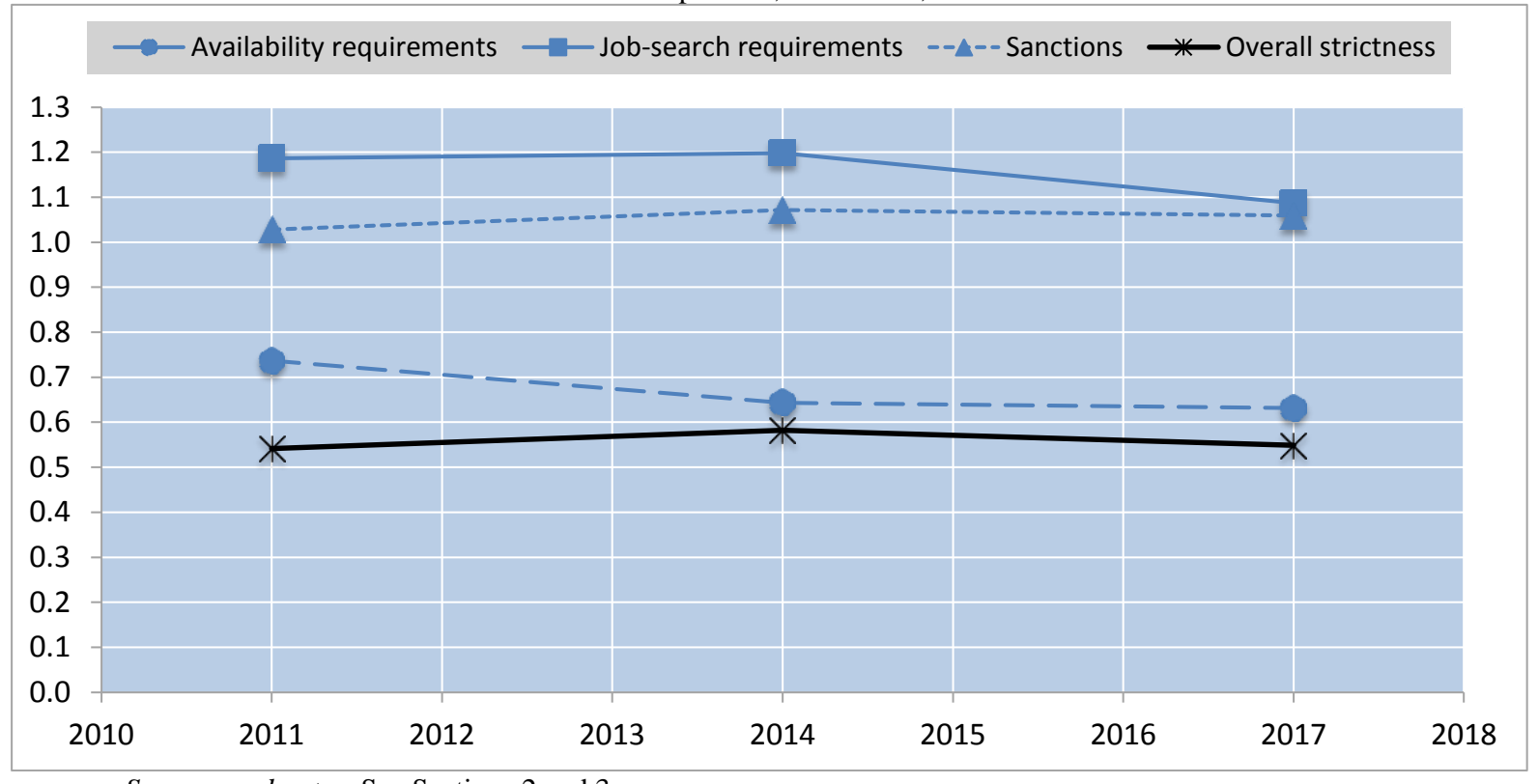

Sources and notes: See Sections 2 and 3. 
9. Eligibility criteria for lower-tier benefit programmes are neither generally stricter nor generally more lenient than for $1^{\text {st }}$-tier benefits. In about half of the reporting countries, overall strictness scores are similar for first and lower-tier programmes. $1^{\text {st }}$-tier benefit claimants are subject to tighter rules in about 20 per cent of countries, mostly as a result for tighter sanctioning provisions in $1^{\text {st }}$-tier programmes (e.g., Denmark, Estonia, Lithuania, Luxembourg, and Norway). The remaining 30 percent of countries paper more demanding eligibility conditions for claimants of lower-tier programmes, typically as a result of tighter availability and job-search requirements (e.g., Austria, Canada, Cyprus, Italy, Japan, and United Kingdom).

10. The remainder of this paper proceeds as follows. Section $\mathbf{2}$ discusses the relevance of eligibility criteria for the functioning of unemployment benefits and provides a short summary of empirical research on the effects of eligibility rules. It also illustrates longer-term policy trends over the past three decades, and their association with labour-market conditions, suggesting that links between policy choices and employment can be complex, with possible causal links in either direction. Section 3 summarises the data collection process and describes the resulting indicator for measuring the strictness of eligibility criteria. The full set of questionnaire responses is summarised in a comprehensive Annex. Due to its size, which reflects the scope of the survey conducted for this study, the annex is made available online. Section 4 presents results for $1^{\text {st }}$-tier unemployment benefits and summarises reforms that countries undertook since 2014. Section 5 presents new results on eligibility benefits for lower-tier assistance benefits, and discusses if and how they differ from first-tier unemployment benefits. A final section concludes and considers potential analytical uses of the emerging time series of benefit eligibility rules across countries. 


\section{The design of unemployment benefits and the role of eligibility criteria and early intervention measures}

11. The level of benefits paid by unemployment and related out-of-work support programmes is a key element in discussions of benefit generosity, income adequacy for jobseekers, and work incentives. The OECD and others regularly produce indicators of benefit entitlements at the individual or family level (www.oecd.org/social/benefits-and-wages.htm as well as OECD, 1994, 2006, 2007; Salomäki and Munzi, 1999; Immervoll and O'Donoghue, 2001; Esser et al., 2013). However, access to unemployment benefits is not guaranteed or automatic for jobless individuals, but subject to a broad range of conditions (see e.g., Atkinson and Micklewright, 1991; OECD, 2007, 2015; Clasen and Clegg, 2007).

12. A first set of conditions may exclude certain groups from receiving unemployment benefits altogether. These conditions are frequently referred to as entitlement conditions (Langenbucher, 2015). To be entitled to unemployment insurance benefits, claimants are typically required to have a minimum employment or contribution record (e.g. a worker must have paid contributions into the insurance fund for at least 12 months in the 24 months before becoming unemployed). Individuals with shorter employment records or less continuous work histories are not covered. More complex rules may apply for subsequent unemployment spells in a number of countries (for instance, shorter contribution records may be required or participation in ALMPs may generate new rights to unemployment insurance). Unemployment assistance may be available to those not (or no longer) entitled to insurance benefits, but is subject to a means-test, limiting entitlement to those living in households with no or little income or assets. Information on entitlement criteria is available through the OECD's country descriptions of tax and benefit programmes. The OECD uses this information to formalise entitlement rules into computer models that simulate benefit entitlements for a range of "typical" labour-market and family situations. The results of these models, in turn, support the construction of annually updates indicators of benefit generosity, income adequacy during unemployment, and work incentives (www.oecd.org/social/benefits-and-wages.htm).

13. In addition, there are different, often behavioural, requirements, which have to be met by those who have established a right ("entitlement") to receive unemployment benefits in principle. These activity-related eligibility criteria are the subject of this paper and cover (i) requirements to be available for employment, (ii) job-search and reporting requirements, and (iii) sanctions for non-compliance with applicable requirements. Eligibility criteria vary considerably across countries and have also changed markedly over time (see Box 1). 
14. A third category of design and implementation features of unemployment benefits concern procedural aspects of how jobseekers interact with public authorities when they apply for benefits, register for job placement, arrange meetings, and obtain referrals to job vacancies. These registration procedures and related early intervention measures do not, strictly speaking, fall into the realm of eligibility criteria and are therefore not included in the indicators presented below. However, they nonetheless shape the overall activation stance and the accessibility of support for the unemployed. Jobseekers may, for instance, only be able to sign up for unemployment benefits once they have registered for job placement with an employment service provider (usually a public employment service). Where application for benefits and registration for placement are separated, there may be a certain time limit within which claimants need to complete both steps. And, finally, mandatory waiting periods may delay the start of benefit payments by several days or longer from the time the application for benefits was filed. Together, these provisions may therefore reduce the administrative workload for benefit administrations and/or employment services by discouraging jobseekers from applying for benefits in certain situations, e.g., if they expect to be unemployed for only brief periods of time. Registration procedures may also dissuade employers from dismissing their workers for short periods of time (e.g., following some seasonal pattern) in the expectation that their workers will be compensated through unemployment benefits (Borjas, 2010, 521-523). Registration procedures have been documented in previous OECD studies on public employment services and activation strategies (OECD, 2005, OECD, 2015). Building on these earlier studies, the present paper provides a brief descriptive update of the procedures that countries operate. 


\section{Box 1. Have eligibility criteria become tighter over the last decades?}

A research project at Lund University in Sweden has assembled a long time series on the strictness of eligibility criteria in 21 advanced OECD economies between 1980 and 2012 (Knotz and Nelson, 2015). These data provide a previously unavailable historical perspective on the development of eligibility rules, and can be used to assess to what extent, and in which respects, eligibility rules have changed over time, e.g., whether there has been a general trend towards benefit systems becoming more "activating" (Eichhorst et al., 2008). The data collection was, in part, inspired by earlier OECD data collections for more recent years (Venn, 2012). Although the scope and methods are not exactly the same in the Knotz and Nelson (2015) study, some parts of the historical data can be combined with the OECD data starting in year 2011 to create long time series covering 1980 to 2017.

The combined series, drawing on the 2017 data presented in this paper, highlights some noteworthy trends in eligibility criteria for which information that is available throughout the period, including a notable tightening of jobsearch and reporting requirements. In 1980 a majority of countries did not require jobseekers to paper their job-search activities, while this share has dropped to around 10\% in 2017 (Figure 2.1, Panel A). Most countries nowadays require claimants to paper at least in undefined intervals. The 2017 data presented in this paper indicates, however, that the share of countries providing for a specific frequency of job-search reporting has fallen somewhat, while more countries require reporting at undefined intervals. To some extent, this is because countries have moved towards on-line job portals and digital search diaries, which need to be kept up to date at all times but which case workers can check at their own discretion (Denmark is an example; see below for details). But the trends may also reflect a desire by policymakers to allow for a greater degree of discretion from caseworkers more generally. A related development is that countries increasingly make use of so called jobseeker agreements (or intensive action plans), which lays down how jobseekers should go about searching for new employment and how employment service provider will assist them (Panel B). 
Figure 2. Share of countries with different "activating" elements built into benefit eligibility conditions

Panel A. Reporting requirements.

Panel B. Jobseeker Agreements (JSA)
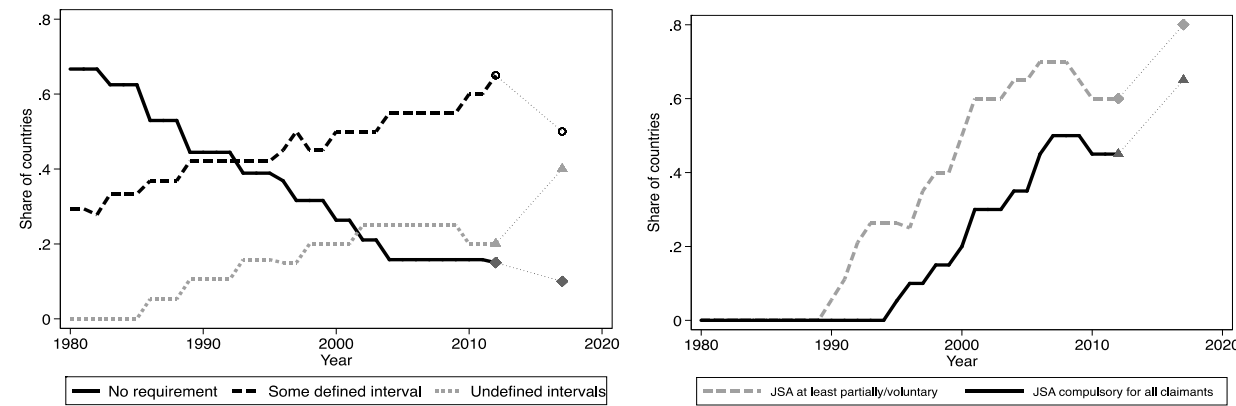

Source: This paper (for 2017 data), as well as Knotz and Nelson (2015), see also Knotz (forthcoming).

Another notable trend is the tightening of sanctioning rules between 1980 and the early 2000s (Figure 2.2). A synthetic indicator of sanction strictness points to sanction provisions becoming more stringent across countries in the 1980s and 1990s (Panel A, the indicator averages scores for the strictness of sanctions for voluntary unemployment, and for initial and subsequent refusals of suitable job offers, see below). Yet, following a peak around the year 2000, sanction rules became somewhat less strict in the early 2000s and then remained broadly unchanged since then and throughout the post-crisis period. The time-series for the United Kingdom illustrates the policy developments driving these trends (Panel B). The British governments tightened sanctioning rules on three occasions: Twice in the 1980s, when disqualification periods were lengthened, and once in 2012, when a stepwise sanctioning schedule with disqualification periods were introduced, with up to three years for repeated refusals of job (see also Clasen, 2011).

Figure 3. Strictness if benefit sanctions
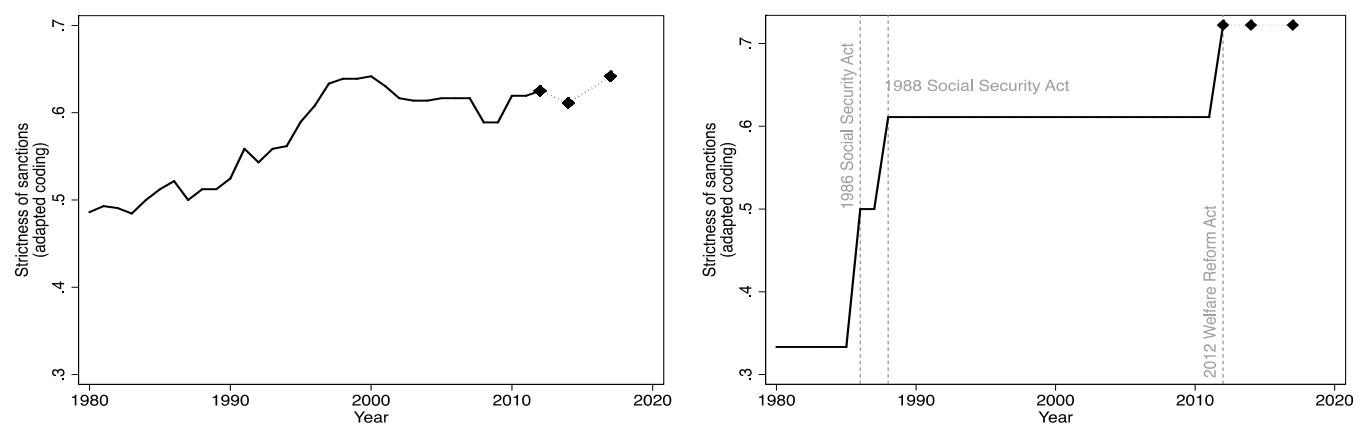

Source: This paper (for 2017 data), as well as Knotz and Nelson (2015), Venn (2012), Langenbucher (2015), Knotz (forthcoming).

15. Together, eligibility criteria and related administrative provisions or practices are designed to boost incentives to look or prepare for employment, preventing continued benefit receipt by those who are not immediately available 
for suitable work, and/or act as a deterrent to claiming benefits. Several studies have shown that job-search monitoring can have a considerable impact on reemployment rates (Graversen and van Ours, 2008; OECD, 2015, citing Borland and Tseng, 2007; Klepinger et al., 2002; McVicar, 2008). For relatively wellqualified jobseekers, however, monitoring may merely shift job search from informal to formal channels (Van den Berg and Van der Klaauw, 2006).

16. The costs of non-compliance with eligibility criteria depend on the extent and likelihood of sanctions being imposed. In addition, the manner in which these possible consequences are communicated to benefit claimants can also play an important role. A number of studies have examined the impact of warnings and the existence of sanctions provisions generally and show that they can substantially shorten benefit claim durations and increase re-employment among individuals who may expect to incur a sanction (Abbring et al., 2005; Boockmann et al., 2014; Lalive et al., 2005; and Van den Berg et al., 2004). This ex-ante effect (also called "threat" effect in the literature) operates before a sanction is actually imposed. Available results also suggest that sanctions do not need to be particularly harsh to have noticeable effects. For instance, Svarer (2011) studies the effects of sanctions in Denmark and finds that relatively mild temporary disqualifications for two or three days have significant effects on the outflow from unemployment. More generally, there is evidence that "soft" eligibility constraints like mandatory participation in ALMPs or gradual reductions of benefit levels over time have effects similar to those of harsher instruments like sanctions (Black et al., 2003, Røed and Westlie, 2012, Fredriksson and Holmlund, 2006).

17. Once a sanction is in fact imposed, the cost of unemployment increases for jobseekers, creating additional incentives for finding and accepting work more quickly than they may otherwise have done (ex-post effect of sanctions, Fredriksson and Holmlund, 2006, Lalive et al., 2005, van den Berg et al., 2004). The positive effect of higher exit rates from unemployment, and higher re-employment rates, can also come at the cost of poorer job matches, a lower quality of post-unemployment outcomes with respect to job stability and earnings (Arni et al., 2013), and a higher probability of working in part-time jobs (Van den Berg and Vikström, 2014), although evidence is mixed (Tatsiramos and van Ours, 2014) and some newer studies find no effect (Le Barbanchon, 2016). There is also evidence of unequal sanction patterns, with economically more vulnerable groups or minorities being sanctioned more frequently than others (Schram et al., 2009, Lee et al., 2004, Wu et al., 2006, Kalil et al., 2002). Some researchers have explored the wider consequences of sanctions and provide some evidence of adverse consequences for child welfare, family welfare, and health outcomes (see Griggs and Evans, 2010 for an overview). When sanctions are imposed for assistance benefits, some countries therefore have safeguards in the system to prevent families with children or other vulnerable claimants from falling below a certain subsistence level (see Section 5 below and OECD, 2015).

18. While much of the economic literature focuses on the economic consequences of different benefit provisions and configurations of countries' activation strategies, it is equally interesting to consider political economy factors shaping countries' policy choices, such as the factors driving reforms of eligibility criteria and the severity of sanctions. Indeed, eligibility criteria and sanctions may not only affect but could also be affected by changes in 
unemployment and otherwise adverse labour-market conditions. For instance, a study of the public debate about support for the unemployed in Germany found that concerns about benefit fraud and "idleness" among the unemployed tend to become salient in times of high unemployment. These public concerns, in turn, appear to facilitate the tightening of access to benefits through the introduction of stricter eligibility conditions (Oschmiansky et al., 2003). The possible two-way relationship between benefit accessibility and labour-market conditions is important to keep in mind when interpreting apparent cross-country relationships between eligibility rules and unemployment rates. Box 2 illustrates these relationships using data for 2014. 


\section{Box 2. Association between labour-market conditions and eligibility criteria}

Empirical studies of the effects of eligibility criteria are frequently country specific and focus on specific groups of jobseekers, or on specific elements of countries' activation approaches. As a backdrop to these empirical results, it can be informative to look at the association between unemployment rates and the strictness of eligibility rules using the emerging cross-country. Simple scatter plots can, to be clear, not be interpreted as evidence for any causal relationship between eligibility conditions and unemployment. Inspection of cross-country data is, however, a useful point of departure, and a possible motivation, for further in-depth micro-level studies, especially for countries or programmes where existing evidence is limited or non-existent.

The three graphs in Figure 4 depict, from left to right, associations between the average unemployment rate during the period from 2011 to 2017 on the vertical axis, and the overall strictness of eligibility criteria, the strictness of sanctions, and the strictness of availability requirements on the horizontal axis. Both unemployment rates and strictness scores refer to the 2011-2017 period. (The strictness scores are averages of 2017 results presented in this paper, and the corresponding 2011 and 2014 vales taken from Venn, 2012 and Langenbucher, 2015). The cross-country relationship between the overall strictness of eligibility criteria and the level of unemployment is very weak and the two other graphs provide clues for why this relationship is not more pronounced. Availability criteria and sanctions show sizeable statistical associations, but they go in different direction: although countries with stricter availability requirements tend to have lower unemployment rates, stricter sanctions are associated with higher unemployment rates. (The third component of overall strictness scores, jobsearch and reporting requirements, are omitted here as they have only a weak relationship with unemployment, driven mostly by a small number of). Although not reported here, similar patterns emerge when extending the observation period using the long time series discussed in Box 2 . 
Figure 4. Eligibility criteria and unemployment

Unemployment rates and strictness indicator scores, 2011-2017
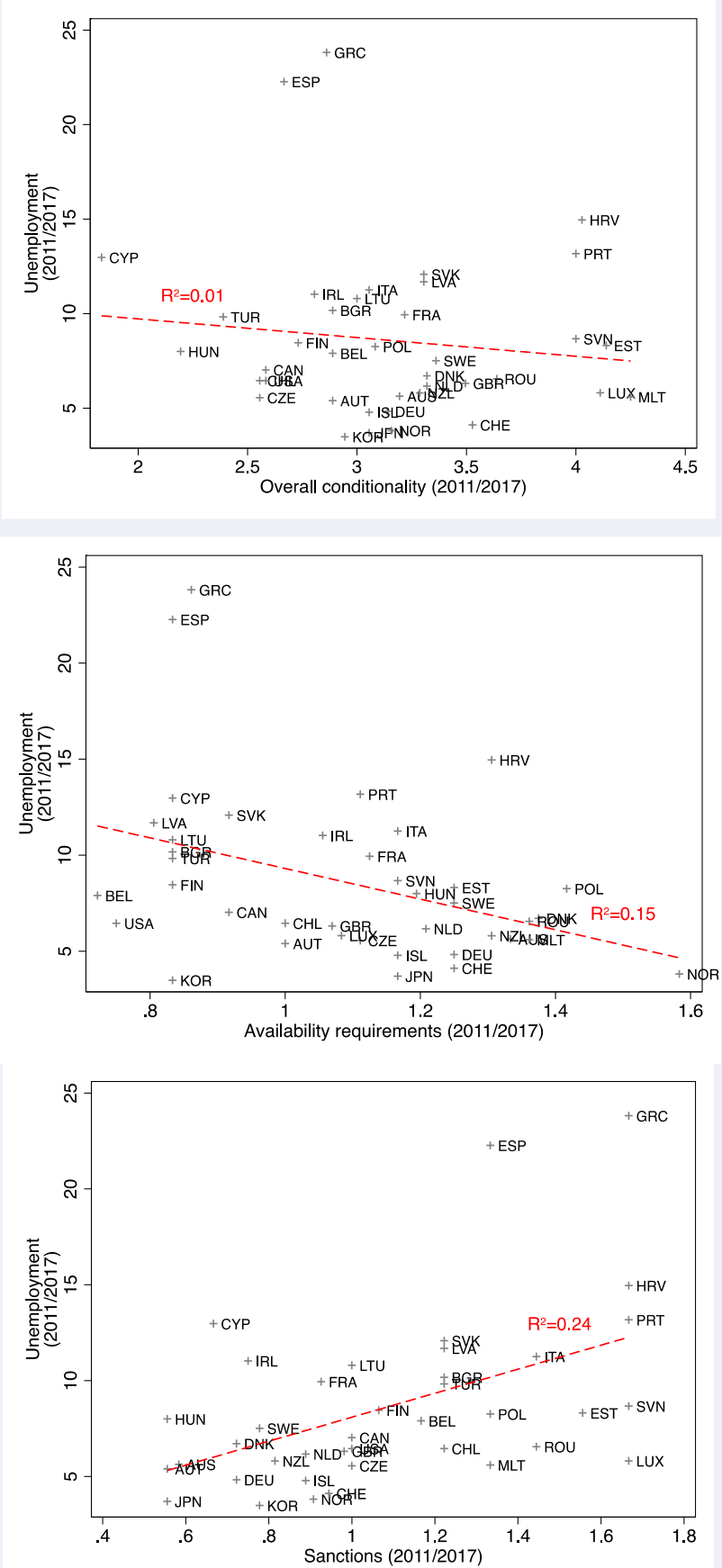

Source and Notes: The 2017 data on eligibility criteria are from this paper, the 2011 and 2014 data are from Venn (2012) and Langenbucher (2015), respectively. Data on unemployment rates for 2017 are for Q1-3 as taken from the EC AMECO database and OECD Short-Term Labour Market data. 


\title{
3. Strictness of eligibility criteria: A policy indicator for monitoring and benchmarking legal provisions
}

\begin{abstract}
19. The OECD has developed a quantitative policy indicator on the strictness of benefit eligibility using data collected via comprehensive expert surveys. Box 3 provides details on the data collection process, building on the work by Venn (2012), Langenbucher (2015), and the Danish Ministry of Finance (Ministry of Finance, 1998; Hasselpflug, 2005). The indicator is designed to enable researchers, policy experts, and others to compare the configuration of eligibility criteria across countries and over time, and to facilitate efforts to monitor how countries balance concerns over targeting, benefit accessibility and work incentives. Where eligibility criteria are lenient, jobseekers can receive unemployment benefits even if they quit their job voluntarily, and they have wide discretion over how to look for new work and which job vacancies to apply for. By contrast, where eligibility conditions are strict, benefits may be granted only to those who are laid off involuntarily, or who had strong objective reasons to resign such as harassment at work), and to those demonstrating intensive jobsearch activities and availability to work in a wide range of possible jobs.
\end{abstract}

20. As policy indicators, the strictness measures presented in this paper, as well as the underlying policy information, relate to the strictness of statutory rules, and not how strictly these rules are enforced in practice. Enforcement can vary even between countries with the same or very similar rules (Grubb 2000), between different time periods with similar statutory rules (e.g., with less strict enforcement during recessions when staff-to-client ratios at benefit administrations or public employment services are low), as well as between different claimant groups in a given country or and year (Schram et al. 2009). There are nevertheless good reasons to consider statutory rules in isolation. First, statutory rules and enforcement in practice are distinct empirical phenomena that warrant measurement on their own. An aggregate indicator that measures statutes and enforcement together might arguably obscure more than it reveals. In addition, deviations, tensions and links between rules and enforcement are interesting phenomena, which can only be studied empirically when separate measurements are available. Collecting information on enforcement practices, e.g., in the form of sanction statistics, is an important topic for future comparative work.

21. Information on statutory eligibility is organised under the following headings.

22. Items 1 to 4: Availability criteria. These criteria determine, put briefly, under which circumstances claimants can restrict their availability for work without losing their right to benefits.

a) Item 1: Availability during ALMP participation. One circumstance in which countries may excuse claimants from availability for 
employment is when they participate in ALMPs such as labour market training schemes. For instance, it might be considered more important that claimants complete their courses first rather than having to accept available jobs quickly. In many countries, claimants are still required to be at least available for, and sometimes to be also actively seeking, employment while participating in ALMPs.

b) Item 2: Occupational mobility requirements. Claimants may be allowed to reject job offers if the vacancy is for an occupation that is different from their last job, or if it pays significantly lower wages. Numerous countries permit claimants to refuse work outside of their own occupation or at lower wages, often in an explicit effort to protect them from downward mobility and protect previously made skill investments (Estévez-Abe et al., 2001, Hummel-Liljegren, 1981), but others expect claimants to accept work in a wide range of occupations or largely irrespective of wage levels.

c) Item 3: Geographical mobility requirements. Claimants may also be required to commute or even relocate in order to acquire and start new employment. Many countries specify a maximum amount of time per day workplace or, alternatively, a maximum distance from their home a claimant can be required to commute to a new job. In some countries, claimants may have to accept to move to a different part of the country.

d) Item 4: Other valid reasons. Countries may permit claimants to refuse offers of employment for reasons other reasons than those presented above. Certain types of jobs - temporary or part-time jobs, or shift work - may be considered unsuitable. Claimants with caring responsibilities, or illnesses or impairments may be exempted from having to accept certain types of jobs. Many countries also specify that claimants do not have to accept work that arises in the context of an industrial dispute (strike, lockout), e.g., if it would require claimants to "cross the picket line". Employment may also be considered unsuitable if it could be considered immoral (e.g. sex work) or if it would violate claimants' religious or ethical beliefs.

23. Items 5 and 6: Job-search requirements and monitoring procedures. While self-motivated jobseekers will often engage in effective jobsearch strategies, regular monitoring of independent job-search efforts is commonly used to ensure that benefit recipients actively search for work throughout their unemployment spell.

- Item 5: Frequency of job-search activity. The required frequency of job-search activities can range from once per week to once in six months. There are also countries where the required job-search frequency is not explicit and some countries do not require claimants to paper their job-search activities at all, but checks of independent job-search efforts may occur as part of intensive interviews.

- Item 6: Documentation of job-search activity. Documentation requirements make jobseekers' efforts verifiable, and based upon feedback about the outcomes of job applications the PES may offer advice to improve job-search techniques. Some countries only require claimants to confirm that they have been looking for work or to keep 
a job-search diary without having to provide specific evidence of jobsearch or applications. In other countries, claimants may have to produce written declarations from employers they have been in contact with.

24. Items 7 to 11: Sanctions. In most countries, legislation for unemployment benefits includes the possibility of sanctions when claimants do not comply with eligibility criteria. Sanctions range from a temporary reduction of benefit payments to a complete and sometimes permanent disqualification from the benefit programmes. The data include information on sanction provisions for five different types of infractions.

- Item 7: Voluntary resignation from employment. In many countries, the involuntary termination of employment is a fundamental condition for eligibility to unemployment benefits upon job loss, and job quits that are judged voluntary result in an automatic disqualification from benefits. In other cases, a voluntary resignation from employment is considered an infraction, e.g., similar to a refusal of available suitable employment, and may be sanctioned with an extended waiting period or a temporary disqualification.

- Item 8: Refusal of suitable employment. Since unemployment benefit claimants in all countries have to be available for offers of suitable employment, there is usually some penalty for refusing such offers. Penalties range from complete to temporary or partial disqualifications.

- Item 9: Repeated refusal of suitable employment. Some countries do not impose sanctions for a first infraction, but instead issue a warning only with sanctions applying to subsequent offences. Subsequent refusals will result in penalties being imposed, which are often successively harsher.

- Item 10: Refusal of ALMP participation. A refusal to participate in a suggested labour market programme is typically considered a failure to cooperate with the employment services and to take steps to get back into work. Referrals to labour market programmes may also be used as an instrument for verifying whether benefit claimants are genuinely committed to finding employment or for ensuring that they are available for work rather than being engaged in informal employment or other activities. ${ }^{1}$

- Item 11: Repeated refusal of ALMP participation. As in the case of repeated refusals of offers of employment, repeated failures to participate in ALMPs may be subject to harsher penalties.

1. See, e.g., Black et al. (2003). 


\section{Box 3. Data collection}

Earlier studies on eligibility criteria by the Danish Ministry of Finance and the OECD have developed and successively extended the questionnaire, the coding scheme, the items included in the aggregate indicator as well the calculation of the indicator itself. In this present study, the coding scheme and the indicator have been left unchanged, but the questionnaire was amended.

As in Venn (2012) and Langenbucher (2015), the present paper on a standardised questionnaire sent to delegates of the OECD Employment, Labour and Social Affairs Committee and of the Indicators Subgroup of the European Union Social Protection Committee. Questions were open-ended, each question corresponded to a single parameter (e.g. occupational mobility requirements), and respondents were asked to describe the rules in place as of January 2017. The questionnaire included policy information that had been provided in response to the previous (2014) OECD questionnaire and respondents could indicate how rules have changed, or simply state that the rules had remained the same.

The questionnaire was modified and extended in four respects. First, several questions on the administration of unemployment benefit claims (registration procedures, communication, job-search monitoring) were added. These aspects were previously considered separately from eligibility criteria proper in three OECD studies on public employment services and activation instruments.

Second, additional questions on sanctioning rules were added. Earlier OECD studies collected information on sanctions for voluntary unemployment and for initial and repeated refusals of job offers and participation in ALMPs. Many countries also have additional and more specific sanctions for claimants who fail to undertake or paper job-search activities (or, generally, fail to "actively seek employment"), or fail to attend meetings with their caseworkers or employment. Information on these rules was now collected via additional questions.

Third, a number of clarifications were made to the questions and accompanying information. Somewhat more significant changes were made to the two questions on occupational and geographic mobility requirements. Both these questions were split to collect information on different aspects in separate questions. ${ }^{2}$

2. Previously, respondents were asked to provide information on whether claimants had to accept work in other occupations and which wages they would have to accept in one single question. Similarly, in the case of geographical mobility requirements, respondents were asked for information on whether and how far claimants could be asked to commute, and whether they could be required to relocate. Now, respondents were asked separately for information on occupational mobility requirements and suitable wage levels, and commuting and relocation requirements, respectively. The fact that there is overall considerable stability in the results indicates that these modifications did not affect the responses. 
Fourth, separate questionnaires were included to collect information on the strictness of eligibility conditions and monitoring and job-search procedures for claimants

25. The overall strictness indicator is calculated by aggregating three sub-indicators on availability requirements, job-search requirements and sanctions, respectively. These sub-indicators, in turn, are computed from numerical scores on the eleven items listed above. The coding scheme used to assign scores is shown in Table $\mathbf{1}$.

26. The computation of the three sub-indicators and the aggregate indicators follows the approach of and uses the same weighting scheme as Langenbucher (2015), as detailed in Table 2. All three sub-indicators receive the same relative weight. Within each sub-indicator, all items receive the same weight, except in the case of sanction items 8-9 and 10-11, whose weight is each divided by two to account for the fact that they feature twice for similar categories of infraction.

3. In the previous data collection exercises, respondents were asked to provide information on whether claimants had to accept work in other occupations and which wages they would have to accept in one single question. In the case of geographical mobility requirements, respondents were asked for information on whether and how far claimants could be asked to commute, and whether they could be required to relocate. In the latest data collection for 2017, respondents were asked separately for information on occupational mobility requirements and suitable wage levels, and commuting and relocation requirements, respectively. The fact that there is overall considerable stability in the results indicates that these modifications did not affect the responses. 
Table 1. Coding Framework

\begin{tabular}{|c|c|c|c|}
\hline & Item & Score & Description \\
\hline \multirow{20}{*}{ 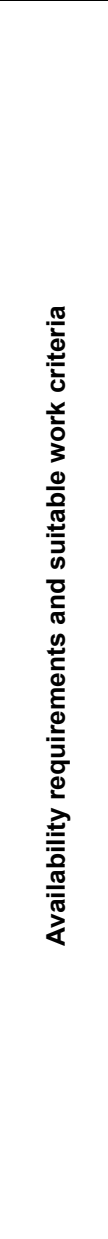 } & \multirow{5}{*}{$\begin{array}{l}\text { Item 1: Availability during } \\
\text { ALMP participation }\end{array}$} & 1 & No demands on availability for work during participation in ALMPs \\
\hline & & 2 & Participation in some ALMPs requires availability for work \\
\hline & & 3 & Participation in most ALMPs requires availability for work \\
\hline & & 4 & $\begin{array}{l}\text { The unemployed should always be available for work while } \\
\text { participating in ALMPs, but are not required to actively search for work }\end{array}$ \\
\hline & & 5 & $\begin{array}{l}\text { The unemployed should always be available and actively searching } \\
\text { for work while participating in ALMPs }\end{array}$ \\
\hline & \multirow{5}{*}{$\begin{array}{l}\text { Item 2: Demands on } \\
\text { occupational mobility }\end{array}$} & 1 & $\begin{array}{l}\text { The unemployed can refuse job offers in other occupational areas or } \\
\text { with lower wages indefinitely }\end{array}$ \\
\hline & & 2 & $\begin{array}{l}\text { The unemployed can refuse job offers in other occupational areas or } \\
\text { with lower wages for a limited period of } 6 \text { months or more }\end{array}$ \\
\hline & & 3 & $\begin{array}{l}\text { The unemployed can refuse job offers in other occupational areas or } \\
\text { with lower wages for a period of less than } 6 \text { months }\end{array}$ \\
\hline & & 4 & $\begin{array}{l}\text { No explicit reservations but the unemployed person's qualifications, } \\
\text { previous remuneration and the length of the unemployment spell are } \\
\text { taken into account }\end{array}$ \\
\hline & & 5 & $\begin{array}{l}\text { The unemployed must accept all job offers that he/she is capable of } \\
\text { doing }\end{array}$ \\
\hline & \multirow{5}{*}{$\begin{array}{l}\text { Item 3: Demands on } \\
\text { geographical mobility }\end{array}$} & 1 & No demands on geographical mobility \\
\hline & & 2 & $\begin{array}{l}\text { The unemployed must accept a daily commuting time of up to } 2 \text { hours } \\
\text { per day }\end{array}$ \\
\hline & & 3 & $\begin{array}{l}\text { The unemployed must accept a daily commuting time of up to } 4 \text { hours } \\
\text { per day }\end{array}$ \\
\hline & & 4 & $\begin{array}{l}\text { The unemployed must accept a daily commuting time of } 4+\text { hours per } \\
\text { day }\end{array}$ \\
\hline & & 5 & The unemployed must be willing to move \\
\hline & \multirow{5}{*}{$\begin{array}{l}\text { Item 4: Other valid reasons for } \\
\text { refusing job offers }\end{array}$} & 1 & Countries with five valid types of reason for refusing jobs ${ }^{a}$ \\
\hline & & 2 & \\
\hline & & 3 & Countries with three or four valid types of reason for refusing jobs ${ }^{a}$ \\
\hline & & 4 & \\
\hline & & 5 & Countries with two or less valid types of reason for refusing jobs ${ }^{a}$ \\
\hline \multirow{5}{*}{ 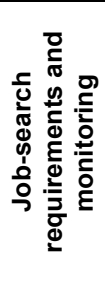 } & \multirow{5}{*}{$\begin{array}{l}\text { Item 5: Frequency of job- } \\
\text { search monitoring }\end{array}$} & 1 & No check of job-search activity \\
\hline & & 2 & Infrequent or ad-hoc checking of job-search activity \\
\hline & & 3 & $\begin{array}{l}\text { Frequency of job-search activities varies for different jobseekers } \\
\text { and/or during the unemployment spell (on average less that quarterly) }\end{array}$ \\
\hline & & 4 & $\begin{array}{l}\text { All unemployed must regularly prove job-search activity (monthly or } \\
\text { quarterly) }\end{array}$ \\
\hline & & 5 & $\begin{array}{l}\text { All unemployed must often i.e. every week or every second week } \\
\text { prove job search }\end{array}$ \\
\hline
\end{tabular}


Table 1. Coding framework (Cont.)

\begin{tabular}{|c|c|c|c|}
\hline & Item & Score & Description \\
\hline \multirow{5}{*}{ 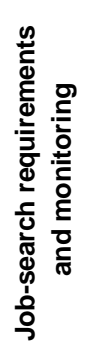 } & \multirow{5}{*}{$\begin{array}{l}\text { Item 6: Documentation of job- } \\
\text { search activities }\end{array}$} & 1 & No formal requirement \\
\hline & & 2 & $\begin{array}{l}\text { The person must regularly affirm that he or she has undertaken some } \\
\text { actions to find work without specifying what these were (e.g. must tick a }\end{array}$ \\
\hline & & 3 & $\begin{array}{l}\text { The person must regularly affirm that he or she has undertaken some } \\
\text { actions to find work and specify what these were (e.g. keeping a job- } \\
\text { search diary) }\end{array}$ \\
\hline & & 4 & $\begin{array}{l}\text { Ine person must regularly supply the name and address (or equivalent } \\
\text { documentation) of emblovers that he or she has contacted }\end{array}$ \\
\hline & & 5 & $\begin{array}{l}\text { The person must regularly produce declarations by employers that he or } \\
\text { she has applied to them for work }\end{array}$ \\
\hline \multirow{25}{*}{ 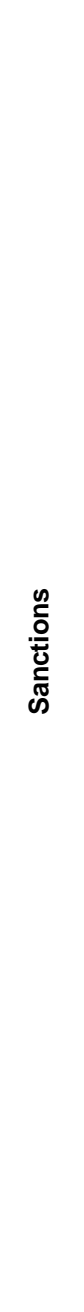 } & \multirow{5}{*}{$\begin{array}{l}\text { Item 7: Sanctions for voluntary } \\
\text { unemployment }\end{array}$} & 1 & 0-4 weeks (including benefit reductions) \\
\hline & & 2 & 5-9 weeks \\
\hline & & 3 & 10-14 weeks \\
\hline & & 4 & More than 14 weeks \\
\hline & & 5 & Ineligible for benefits \\
\hline & \multirow{5}{*}{$\begin{array}{l}\text { Item 8: Sanctions for refusing job } \\
\text { offers }\end{array}$} & 1 & 0-4 weeks (including benefit reductions) \\
\hline & & 2 & $5-9$ weeks \\
\hline & & 3 & 10-14 weeks \\
\hline & & 4 & More than 14 weeks \\
\hline & & 5 & Loss of remaining benefit entitlement ${ }^{\mathrm{b}}$ \\
\hline & \multirow{5}{*}{$\begin{array}{l}\text { Item 9: Sanctions for repeated } \\
\text { refusal of job offers }\end{array}$} & 1 & 0-4 weeks (including benefit reductions) \\
\hline & & 2 & 5-9 weeks \\
\hline & & 3 & 10-14 weeks \\
\hline & & 4 & More than 14 weeks \\
\hline & & 5 & Loss of remaining benefit entitlement ${ }^{b}$ \\
\hline & \multirow{5}{*}{$\begin{array}{l}\text { Item 10: Sanctions for refusal/ } \\
\text { failure to participate in counselling } \\
\text { interviews or ALMPs }\end{array}$} & 1 & 0-4 weeks (including benefit reductions and sanctions until compliance) \\
\hline & & 2 & 5-9 weeks \\
\hline & & 3 & 10-14 weeks \\
\hline & & 4 & More than 14 weeks \\
\hline & & 5 & Loss of remaining benefit entitlement ${ }^{b}$ \\
\hline & \multirow{5}{*}{$\begin{array}{l}\text { Item 11: Sanctions for repeated } \\
\text { refusal/ failure to participate in } \\
\text { counselling interviews or ALMPs }\end{array}$} & 1 & 0-4 weeks (including benefit reductions and sanctions until compliance) \\
\hline & & 2 & $5-9$ weeks \\
\hline & & 3 & 10-14 weeks \\
\hline & & 4 & More than 14 weeks \\
\hline & & 5 & Loss of remaining benefit entitlement ${ }^{\mathrm{b}}$ \\
\hline
\end{tabular}


Notes to Table 1:

a. Valid reasons for refusing jobs are grouped into the following types: i) Family or personal reasons (e.g. caring responsibilities; spouses' work, lack of child care, etc.); Own health or disability; iii) Other working arrangements of the job (e.g. part-time, temporary contract, anti-social working hours, etc.); iv) Moral or religious reasons; and v) Job is to replace workers on strike or lockout, or working conditions to not comply with relevant local or sectorial collective agreement. Refusal of job offers due to the wage offered being lower than the previous wage (or a proportion thereof) or unemployment benefit is included in Item 2 on demands on occupational mobility, was previously scored in Item 4. It is assumed that all countries require suitable jobs to have wages and working conditions consistent with legal requirements (including administrative extensions of collective agreements), that certain types of work (e.g. prostitution) are not considered suitable work and that the unemployed should not be forced to join or leave a trade union or other organisation in order to take up a new job. b. In some countries, as a sanction benefit entitlement may be suspended indefinitely but the individual has the possibility of re-earning her right to receive benefits after a period in paid employment or training (shorter than the usual statutory qualifying period). In such cases, a score of 4.5 rather than 5 has been assigned. Sanction regimes in these countries are treated as stricter than in countries which impose fixed-duration sanctions, but less strict than in countries where unemployment benefit claimants are completely disqualified.

Table 2. Overall strictness indicators: Weighting of individual items

\begin{tabular}{|c|c|c|}
\hline Sub-indicator & Item & $\begin{array}{l}\text { Weight in overall } \\
\text { summary indicator }\end{array}$ \\
\hline \multirow[t]{5}{*}{ Availability requirements } & & 0.33 \\
\hline & 1. Availability during ALMP participation & 0.08 \\
\hline & 2. Demands on occupational mobility & 0.08 \\
\hline & 3. Demands on geographical mobility & 0.08 \\
\hline & 4. Other valid reasons for refusing job offers & 0.08 \\
\hline \multicolumn{2}{|c|}{ Job-search requirements and monitoring } & 0.33 \\
\hline & 5. Frequency of job-search monitoring & 0.17 \\
\hline & 6. Documentation of job-search monitoring & 0.17 \\
\hline \multirow[t]{6}{*}{ Sanctions } & & 0.33 \\
\hline & 7. Sanctions for voluntary unemployment & 0.11 \\
\hline & 8. Sanctions for refusing job offers & 0.06 \\
\hline & $\begin{array}{l}\text { 9. Sanctions for repeated refusal of job } \\
\text { offers }\end{array}$ & 0.06 \\
\hline & $\begin{array}{l}\text { 10. Sanctions for refusing PES activities or } \\
\text { ALMP placements }\end{array}$ & 0.06 \\
\hline & $\begin{array}{l}\text { 11. Sanctions for repeated refusal of PES } \\
\text { activities or ALMP placements }\end{array}$ & 0.06 \\
\hline Sum of weights & & 1.00 \\
\hline
\end{tabular}




\section{Eligibility criteria for $\mathbf{1}^{\text {st }}$-tier unemployment benefits: Results for 2017 and recent changes}

27. In most OECD and EU countries, benefit systems feature rules defining the suitability of job offers, requirements to paper on the outcomes of independent job-search efforts, the obligation to participate in ALMPs, as well as sanctions for non-compliance with these rules. Such rules may be intended as a targeting device, or to ensure that new entrants to unemployment who are relatively employable look for and find a new job independently.

\subsection{Overall strictness of eligibility criteria and changes since 2014}

28. Figure 4.1 depicts how countries compare with respect to the overall strictness indicator. Malta, Luxembourg, Croatia, and Estonia form the group of countries with the strictest eligibility criteria, while Cyprus, the Czech Republic, Turkey, and Hungary operate the most lenient rules according to the overall indicator. Across countries, scores for job-search reporting requirements and sanctions vary relatively strongly (a standard deviation of around 0.36 ), while scores for availability criteria are more homogenous (a standard deviation of 0 . 21). The variability of the overall strictness indicator has declined slightly compared to the 2014 compilation of eligibility rules (the standard deviation decreased from 0.58 to 0.55 ), suggesting a slight convergence of strictness as measured here.

29. Changes in the overall score during the 2014-2017 period reflect substantive reforms in a number of areas. In addition, in some cases, differences relative to the results published in Langenbucher (2015) and Venn (2012), reflect clarifications received from countries rather than substantive policy changes. Reforms leading to reduced strictness scores include the following:

- Australia and Denmark have relaxed job-search requirements. Benefit claimants in Australia now have to paper once a month instead of fortnightly as in 2014). In Denmark, job-search activities are now monitored via an online tool rather than during personal meetings.

- Ireland was assigned a slightly lower score due to changes to the occupational mobility requirements introduced since 2014 (there is no hard rule regarding job offers that can be rejected, but rules allow for greater consideration of any previous work experience or qualifications).

30. Reforms that tightened eligibility criteria were more common since 2014. 
- Finland, France, Italy and Norway tightened applicable sanction provisions. Finland now provides for a tougher penalty for claimants who refuse to accept jobs for which they were explicitly selected. In France, voluntary unemployment now may result in a complete disqualification from benefit receipt, compared to a temporary disqualification for four months as before. Italy introduced new sanctioning provisions in 2015. Tighter sanctions now apply for initial and repeated refusals of job offers, as well as for repeated refusals to participate in ALMPs. However, sanctions for first refusals to participate in ALMPs were relaxed.

- Hungary's score increased noticeably as ALMP participants in some programmes now have to be available for work and because of a tightening of job-search monitoring procedures in 2016.

- Luxembourg operates a new online job-search documentation system ("JobBoard") since 2016, resulting in tighter monitoring of claimant job-search activities. Malta introduced more frequent jobsearch reporting (every other week instead of once a month) but also made availability requirements for ALMP participants slightly less stringent.

Figure 5. Benefits eligibility criteria: Overall strictness indicator for $1^{\text {st }}$ tier benefits

Scored from 1 (most lenient) to 5 (most strict), 2017 and changes since 2011

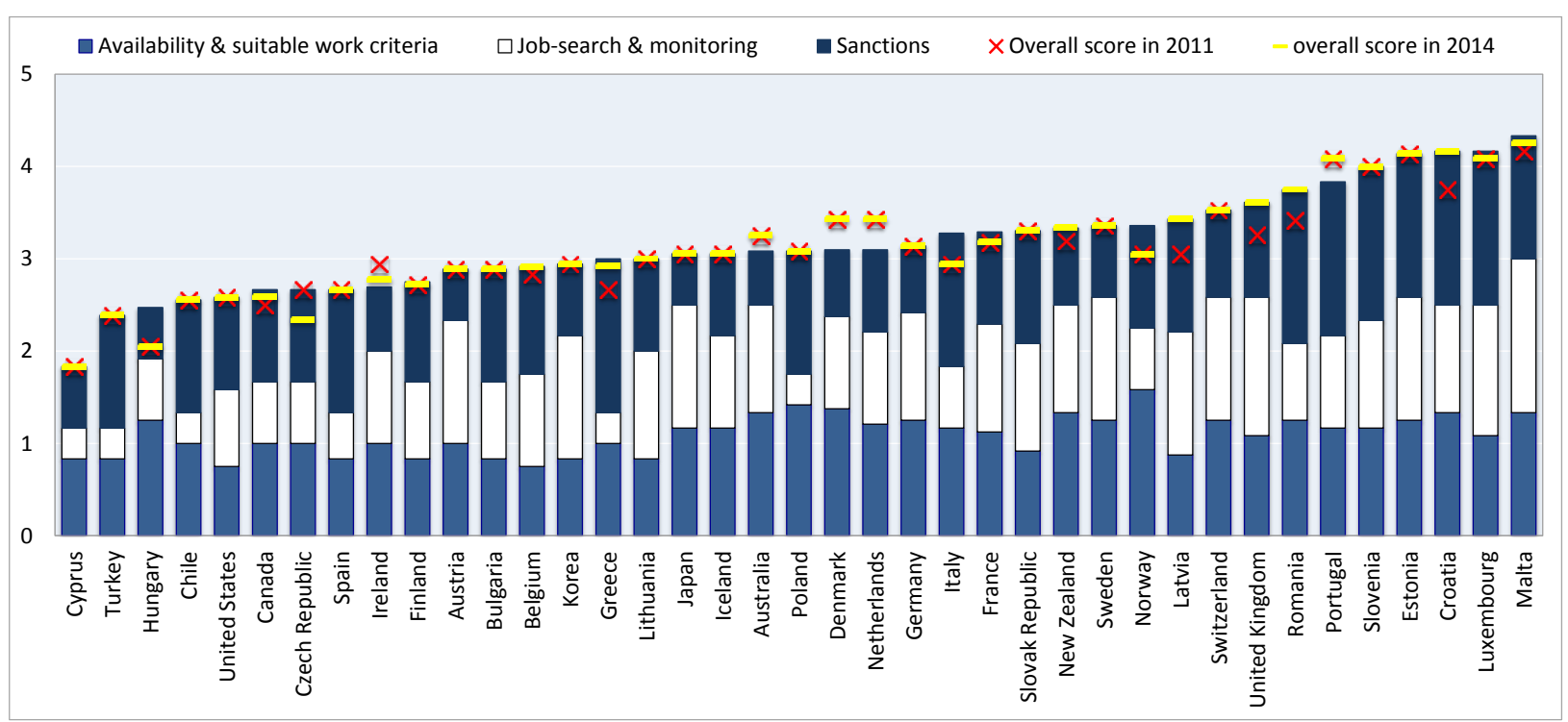

31. A number of countries have implemented several changes simultaneously, some making eligibility stricter and others easing requirements:

- Canada significantly amended its regulations on suitable work, which now includes relaxed occupational mobility requirements but also additional demands regarding geographical mobility along with a 
shorter list of other valid reasons for refusing a job offer. Overall, this manifests itself in an overall slightly higher score compared to 2014.

- The United Kingdom relaxed the requirement to be available for and seeking work while participating in ALMPs. The degree of occupational protection was lowered, however, and job-search documentation requirements were slightly tightened. On balance, the United Kingdom was assigned the same overall score as in 2014.

32. Country results for the different sub-indicators and items are summarised in the sections below.

\subsection{Availability requirements and suitable work criteria}

33. Figure 6 ranks countries' strictness of availability requirements from lenient to strict. Norway, Poland, and Denmark have the strictest rules in place, followed by New Zealand and Malta. At the other end of the scale are Belgium, Greece, the US, and Bulgaria.

Figure 6. Availability requirements and suitable work criteria, 2017

Scored from 1 (most lenient) to 5 (most strict)

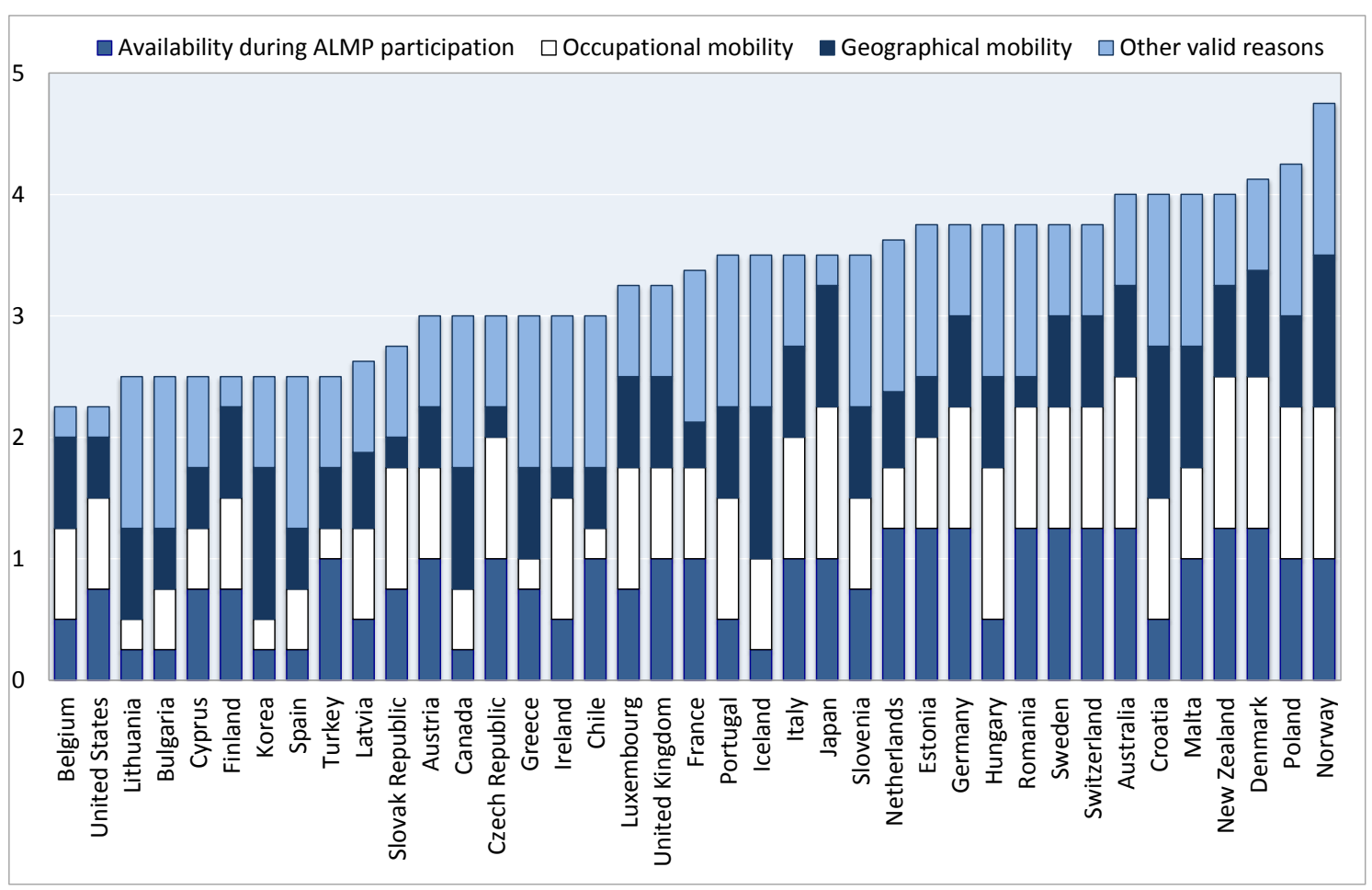

\subsubsection{Item 1: Availability during ALMP participation}

34. Unemployed workers who participate in ALMPs are generally exempt from the requirement to be available for employment in Bulgaria, Canada, Iceland, Korea, and Spain. 
35. Other countries, including Latvia, Ireland, and Croatia, impose availability requirements on selected groups (for instance, ALMP participants in Croatia are generally not classified as active jobseekers, but those participating in training programmes organized by the employment services are). Hungary is now also included in this group as the response received in 2017 indicates that although there is no general requirement to be available for work, some participants are in practice still expected to be available for work.

36. In several countries, ALMP participants are treated like all other unemployed and hence need to be both available for and actively seeking employment. This group includes Australia, Denmark, Estonia, Germany, the Netherlands, New Zealand, Romania, Sweden, and Switzerland. While Malta belonged to this group in 2014, the response received in 2017 indicates that ALMP participants are currently not required to be actively seeking work (although they must remain available). The United Kingdom also reported that the requirements for ALMP participants can be less strict than for other registered jobseekers.

\subsubsection{Items 2 to 4: Criteria on the suitability of employment}

37. Jobseekers will usually have a preference for particular occupations, localities, and wage levels. As these preferences may impact on the likelihood of finding employment, unemployment benefit legislation in the majority of countries defines criteria for what constitutes a "suitable job". Suitable-work criteria can be presented in in three categories: i) required occupational mobility; ii) required geographic mobility; and iii) other valid reasons for refusing job offers.

\section{Item 2: Occupational mobility requirements}

38. Several countries allow workers to restrict their job search and availability to employment within their previous occupation or at a wage comparable to their earlier pay (Bulgaria, Canada, Cyprus, Greece, Korea, the Netherlands, Spain, and Turkey).

39. Most countries, however, permit such limitations only partly or only for a certain duration of during the unemployment spell (Austria, Belgium, Chile, Croatia, the Czech Republic, Estonia, Finland, France, Germany, Iceland, Ireland, Italy, Latvia, Luxembourg, Malta, the Netherlands, Romania, the Slovak Republic, Slovenia, Spain, Sweden, Switzerland, the United Kingdom, and the United States).

40. Poland, Norway, New Zealand, Hungary, Denmark, and Australia do not permit the unemployed to reject job offers at lower wage levels or in a different occupation, although claimants typically cannot be required to accept jobs for which they are not qualified (put differently, claimants cannot be expected to accept jobs for which they are underqualified, but they can be required to accept jobs for which they are overqualified). In Japan, claimants can refuse jobs that are not appropriate in light of their abilities. Although in practice, claimants are unlikely to be referred to jobs that do not match their preferences, the authors understand 
that there is no explicitly specified right for jobseekers to limit their availability to their usual occupation

41. Canada, Ireland, and the Netherlands recently modified their occupational mobility requirements. In July 2016, Canada replaced the earlier rules, imposing different requirements depending on claimants' unemployment record and contribution payments. The new rules allow claimants to limit their availability to their previous occupation for a 'reasonable period' (not further defined) and at wages and conditions equal to those of their previous jobs. The Netherlands introduced similar changes in 2015, now requiring claimants to be available for employment in other occupations and at lower wages after a period of six months instead of 12 months as before. Claimants in Ireland used to be required to be available for all types of jobs, but they are now allowed to limit their availability to jobs within their usual occupation for some reasonable period of time, provided that finding such work is deemed realistic.

\section{Item 3: Geographic mobility requirements}

42. Jobseekers claiming benefits are typically expected to commute or to move to a new location where suitable employment is available, albeit within certain limits. Most countries define these limits specifically in terms of the maximum amount of time one can be required to spend commuting per day. In Australia, for instance, commuting up to 90 minutes each way is considered suitable (a lower maximum of 60 minutes applies to parents and to jobseekers with reduced work capacity). Similar commutes can be mandated in Denmark and Finland (up to 3 hours daily) but also in geographically small Luxembourg (up to 2.5 hours). Other countries specify commuting requirements in terms of the maximum distance rather than time $(30 \mathrm{~km}$ distance between residence and job in Greece, $50 \mathrm{~km}$ in Bulgaria and Croatia, $30 \mathrm{~km}$ in France but only after six months of unemployment). A third group of countries specifies commuting requirements in terms of costs (commuting costs up to a share of 20 per cent of the expected gross salary in Latvia, 15 per cent in Estonia). In New Zealand and the Slovak Republic, geographical mobility requirements are determined on a case-by-case basis. Finally, a small number of countries can require moves to a different locality (Norway, Croatia, Iceland, and Korea).

43. Several countries introduced reforms since 2014. In Canada, a new definition of suitable work no longer specifies explicit geographic mobility requirements (instead, in determining whether and how far unemployed workers can be expected to commute, claimant's health and physical capabilities are to be considered). Relocation assistance for jobseekers willing to move has become available in Australia starting July 2014, and in the Czech Republic in 2016. Romania also introduced a new type of subsidy in 2017, while Sweden abolished relocation assistance for such jobseekers in 2015.

44. The Czech Republic, Finland and Romania provided clarifications of the earlier data collected in 2014. In the Czech Republic and Romania, both countries that received the highest score in 2014, there is in fact no 
statutory requirement for jobseekers to be geographically mobile at all (both countries' scores were accordingly lowered to 1). In Finland, a minor clarification concerns the modes of transport that are assumed for calculating commuting times.

\section{Item 4: Other valid reasons for refusing job offers}

45. The number and types of additional suitable-work criteria differ significantly between countries. Australia and New Zealand, for instance, have comparatively long and detailed lists of reasons for which a particular job would not be considered suitable. Factors taken into account include the claimant's health, family care responsibilities and access to childcare, religious or moral beliefs, or whether the job would involve enlistment in the armed forces. In Belgium, special exceptions apply to artists. Many countries also specify that employment would not be suitable if it were to replace workers engaged in lawful industrial action (strike or lockout). This is the case in Germany, Japan, Korea, Austria, Finland, or Switzerland, among others. The coding scheme applied for the purpose of scoring this item considers only a selection of all possibly relevant other reasons (see the note to Table 3 ).

46. Canada and Denmark amended their list of valid reasons for refusing employment offers since 2014. In Canada, the list of valid reasons was condensed to one (if the prospective employer is affected by industrial disputes). The score assigned to Canada was lifted to a 5 accordingly. In Denmark, some valid reasons were deleted, but these did not include any considered by the coding scheme. The score assigned to Denmark was hence not changed.

47. Clarifications were provided by Finland and the Netherlands but did not affect the scores for this item relative to the 2014 value reported in Langenbucher (2015).

\subsection{Job-search requirements and monitoring}

48. Two aspects factor into the stringency of job-search and reporting: The frequency at which claimants have to paper their activities and the extent to which they have to document their activities in a detailed and verifiable way. Figure 7 ranks countries' strictness of job-search and monitoring requirements from lenient to strict. 
Figure 7. Job-search and monitoring requirements, 2017

Scored from 1 (most lenient) to 5 (most strict)

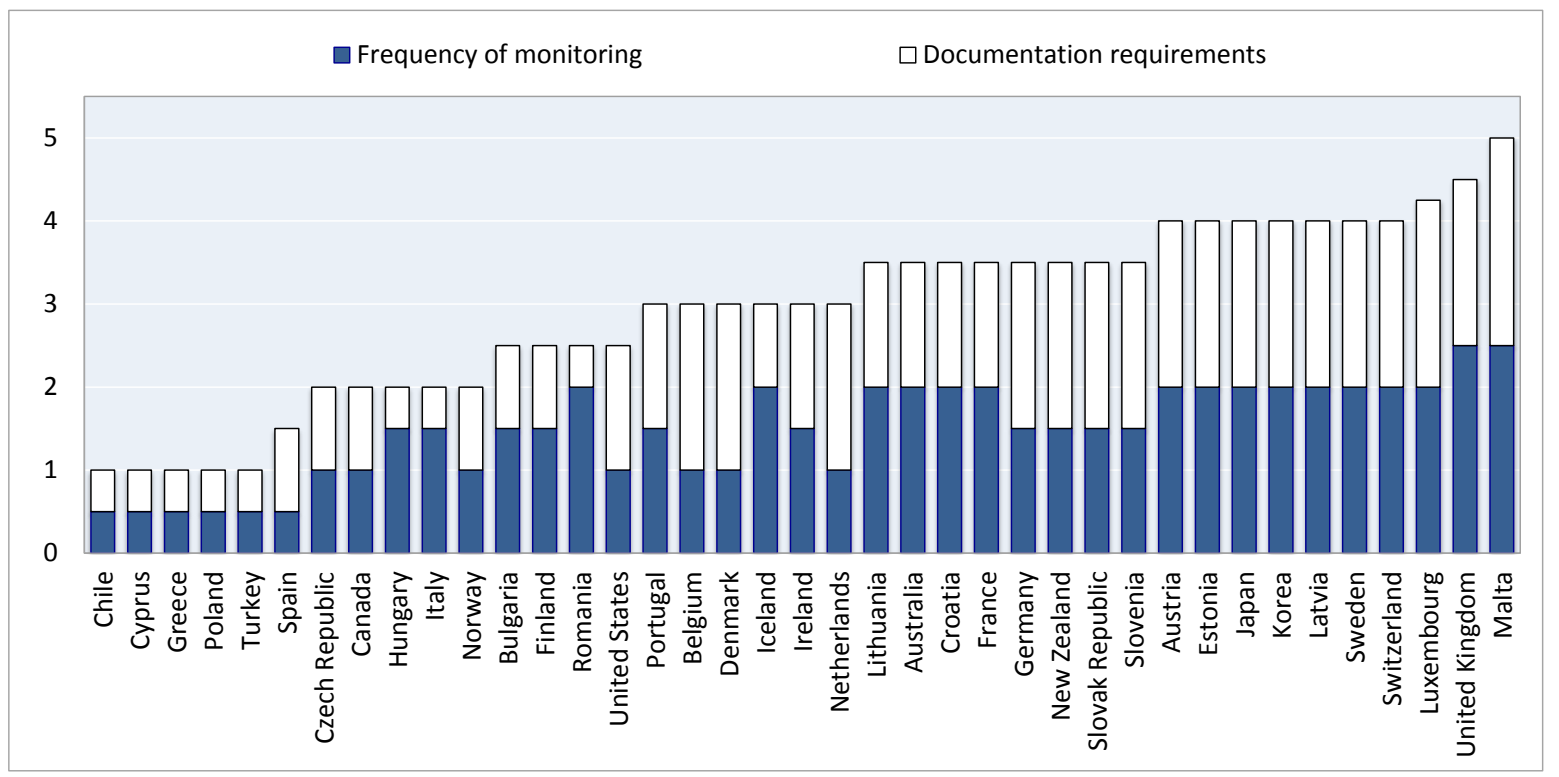

49. Malta and the United Kingdom have the strictest job-search requirements, followed by Luxembourg, Switzerland, and Sweden. In Malta, claimants have to document their job-search activities in detail, including not only whether employers were approached but also the employers' names and addresses, during fortnightly meetings. When claimants undergo training, they need to document these activities as well. In the United Kingdom, claimants need to "sign on" every other week and need to continuously document and provide their job-search activities, either in person or via the Internet. These reporting requirements do vary, however, between claimants depending on their individual circumstances. Sweden operates an online monitoring procedure, where claimants need to detail their job-search actions, including which employers were contacted and what other steps were taken to find employment, in so called "activity papers" that need to be submitted once a month via the online portal of the public employment service.

50. A number of countries do not require unemployment benefit claimants to provide evidence of their job-search activities. In Turkey, for instance, claimants need to be available for employment but do not have to provide evidence that they are in fact also seeking employment. In Poland, Chile, and Cyprus, there is also no formal requirement for claimants to provide evidence of their job-search activities. More detailed information on countries' job-search monitoring procedures can be found in the Annex.

51. Several countries have changed their job-search requirements and monitoring procedures:

- Since 2015, half of all unemployment-benefit claimants in the United Kingdom are being monitored every week instead of every two weeks as part of a trial to investigate the effectiveness of different monitoring procedures (see also OECD, 2014). 
- Hungary introduced a new Job Search Plan in 2016, in which the activities and tasks of jobseekers are determined and which is revised every six months.

- A similar change took place in Italy, where jobseekers' activities are now monitored via the new Individual Service Pact.

- Malta operated a similar procedure in 2014 but has since raised the frequency of checks from monthly to fortnightly.

- Luxembourg introduced a new online portal called "JobBoard", where jobseekers need to create profiles and where available jobs declared to the employment service provider are listed. Applications are checked by the PES before they are sent to employers.

- Smaller changes were introduced in Estonia. Jobseekers with health impairments or reduced work capacity can now paper their job-search activities over the phone or online, as jobseekers with good prospects of finding a job or those participating in ALMPs were able to do before.

- Chile, while still not verifying job-search activities in regular intervals, now requires jobseekers to register with the national employment service (Bolsa Nacional de Empleo, BNE) and submit their CV within 96 hours

- Belgium slightly tightened its monitoring procedures by increasing the age from which jobseekers are exempt from reporting their jobsearch efforts. At the same time, the frequency at which activities are checked was lowered for those under the age of 25 to once every year from previously every nine months and, where job-search efforts are deemed insufficient, new reviews are now conducted after six months instead of four months as before.

- Australia reduced the frequency of required job-search reporting from fortnightly to monthly.

- Denmark now operates an online portal, where jobseekers have to create profiles and upload their applications. These are subject to verification but checks are no longer carried out at explicitly specified intervals.

- Similar changes were introduced in the Netherlands. Claimants now have to provide evidence upon request (although they still have to document their activities online).

52. Some clarifications were provided by the Czech Republic, indicating that, although legislation does not specify the exact frequency at which claimants need to paper their job-search activities, claimants do need to paper their activities both verbally and on a specific form.

\subsubsection{Memorandum item: Registration procedures, contact with employment service and availability for starting employment}

53. In addition, countries operate specific further provisions regarding registration procedures for benefit claimants. These procedures shape the interaction and accessibility of benefits and are a relevant element of countries' activation approaches (see Table 3). However, they are different from the eligibility criteria governing the benefit claiming process, as they 
take effect before benefits are claimed. Country responses on registration procedures indicate that there are large differences across countries. As a result, they represent important contextual information when interpreting the practical consequences of country differences in the strictness of eligibility criteria. For instance, job-search requirements that are relatively strict may not be binding during an initial phase of unemployment if waiting periods are long, or if registration occurs only after a long delay (e.g., only a some weeks after first benefit payments).

54. A final aspect on which information was collected is whether and how jobseekers need to stay in contact with their employment service provider, and how quickly they need to be able to start a new job. As in the previous (2014) study, information on these aspects were collected but could not be included in the indicator on eligibility criteria as several countries do not have clearly defined statutory rules or procedures. The updated information is provided in the Annex. Some movement toward more clearly defined rules is occurring, however, with some countries introducing new explicit rules:

- As part of labour market reforms, Italy introduced specific permissible delays after which jobseekers need to respond to requests from the PES and be ready to start work. From 2015, the maximum delay is 72 hours.

- Latvia introduced the requirement that jobseekers need to attend the employment services (SEA) within three days after having received an invitation.

- Malta now requires jobseekers to provide their contact details (telephone and mobile numbers, email addresses) when registering with the employment services. 
Table 3. Unemployment benefit registration procedure and application routes, 2017

\begin{tabular}{|c|c|c|c|c|c|}
\hline Country & \begin{tabular}{l}
\multicolumn{1}{c}{$\begin{array}{l}\text { Sequencing of benefit } \\
\text { entitlement and registration for } \\
\quad \text { placement }\end{array}$} \\
Benefit entitlement starts before (B), \\
simultaneously with (S), or after (A) \\
registration for placement; $R=$ benefits \\
can be paid retroctively back to date \\
of loss of work
\end{tabular} & $\begin{array}{l}\quad \text { Waiting period } \\
\text { Length of waiting period } \\
\text { (for which benefit is not } \\
\text { paid at start of claim), if any }\end{array}$ & \begin{tabular}{l}
\multicolumn{1}{|c}{ Application routes } \\
Possible application \\
routes: in person $(P)$, \\
telephone $(T)$, fax $(F)$, \\
post $(W)$, e-mail $(E)$, or \\
online $(O)$ \\
\end{tabular} & $\begin{array}{l}\text { Online registrations } \\
\text { Share of claimants } \\
\text { registering online }\end{array}$ & \begin{tabular}{|l}
\multicolumn{1}{|c}{ Delay } \\
Delay until first contact \\
with job-placement \\
services
\end{tabular} \\
\hline Australia & S & 7 days & $\mathrm{P}, \mathrm{W}, \mathrm{T}, \mathrm{O}$ & $87 \%$ & $\begin{array}{l}\text { Usually } 2 \text { days (14 days } \\
\text { max.) }\end{array}$ \\
\hline Austria & $s$ & 1 & $\mathrm{~T}, \mathrm{~F}, \mathrm{~W}, \mathrm{O}$ & About 5\% & Max. 10 days \\
\hline Belgium & $B$ & 1 & $P^{\text {a) }}$ & $x$ & $\begin{array}{l}\text { No enforced maximum } \\
\text { delay }\end{array}$ \\
\hline Bulgaria & $A, R$ & 1 & $\mathrm{P}$ & $x$ & 7 days \\
\hline Canada & B & 7 days & $\mathrm{O}, \mathrm{w}$ & $98.5 \%$ & $\begin{array}{l}\text { Not applicable, direct } \\
\text { visits not required }\end{array}$ \\
\hline Chile & $B$ & $\begin{array}{l}\text { Variable, depending on } \\
\text { timing of application }\end{array}$ & $\begin{array}{l}\text { Claimants need to } \\
\text { register for employment } \\
\text { at PES (BNE) }\end{array}$ & & $\begin{array}{l}\text { Registration with BNE } \\
\text { within } 96 \text { hours }\end{array}$ \\
\hline Croatia & S, R & & $P$ & $x$ & $\begin{array}{l}\text { Not applicable, claimants } \\
\text { apply in person at the } \\
\text { PES }\end{array}$ \\
\hline Cyprus & A & 3 days & P & $x$ & Same day \\
\hline Czech Republic & A, $R$ (only for the first 3 days) & 1 & $P$ & $x$ & $\begin{array}{l}\text { No limit, but entitlement } \\
\text { to benefits depends on } \\
\text { registration }\end{array}$ \\
\hline Denmark & s & 1 & $P, O, T^{b)}$ &.. & 6 weeks \\
\hline Estonia & s & 7 days & $\mathrm{P}, \mathrm{O}$ & $13.8 \%$ & 30 days \\
\hline Finland & A & 7 days & $\mathrm{W}, \mathrm{O}^{\mathrm{cl}}$ & $66 \%$ & Within 14 days \\
\hline France & A & 7 days & $O^{\text {d) }}$ & $72 \%$ & 2-4 weeks \\
\hline Germany & S & 1 & P & $x$ & Not applicable \\
\hline Greece & s & 6 days & $\mathrm{P}$ & $x$ & Not applicable \\
\hline Hungary & A & 1 & $P, O$ & About $40 \%$ & 8 days \\
\hline Iceland & B, R & 1 & 0 & $100 \%$ & 4 weeks \\
\hline Ireland & S, R & 3 days & $P, O$ & $0.4 \%$ &.. \\
\hline \multicolumn{6}{|l|}{ Israel } \\
\hline Italy & S & 8 days & o & $100 \%$ & $\begin{array}{l}\text { No enforced maximum } \\
\text { delay }\end{array}$ \\
\hline Japan & A & 7 days & P & $x$ & Not applicable \\
\hline Korea & A & 7 days & P & $x$ & 1-4 weeks \\
\hline Latvia & A & 30 days ( 1 month) & $\left.P, O, W^{e}\right)$ & $x$ & Not applicable \\
\hline Lithuania & A & 7 days & $P, O$ & $5.7 \%$ & $\begin{array}{l}\text { Up to } 5 \text { days (when } \\
\text { registering online) }\end{array}$ \\
\hline Luxembourg & A, R & 1 & P & $x$ & Not applicable \\
\hline Malta & s & 1 &.. & &.. \\
\hline Netherlands & B, R & 1 & $P, O$ & $95 \%$ & $\begin{array}{l}\text { No enforced maximum } \\
\text { delay }\end{array}$ \\
\hline New Zealand & $B$ & $0-14$ days & $P, T, O$ & $37.5 \%$ & $\begin{array}{l}\text { No enforced maximum } \\
\text { delay }\end{array}$ \\
\hline Norway & A & 3 days & $P, W, O$ &.. & 3 months \\
\hline Poland & A & 1 & $P, O$ &.. & 7 days \\
\hline Portugal & A & 1 & $P, O$ &.. & Usually 3 days \\
\hline Romania & S, R & 1 & P & $x$ & Not applicable \\
\hline Slovak Republic & S, R & 1 & P & $x$ & Not applicable \\
\hline Slovenia & S, R & 1 & $P, W, O$ & $2.1 \%$ & Usually within 14 days \\
\hline
\end{tabular}


Table 3. Unemployment benefit registration procedures and application routes, 2017 (contd.)

\begin{tabular}{|c|c|c|c|c|c|}
\hline Country & \begin{tabular}{l}
\multicolumn{1}{c}{$\begin{array}{l}\text { Sequencing of benefit } \\
\text { entitlement and registration for } \\
\text { placement }\end{array}$} \\
$\begin{array}{l}\text { Benefit entitlement starts before }(B), \\
\text { simultaneously with }(S), \text { or after }(A) \\
\text { registration for placement; } R=\text { benefits } \\
\text { can be paid retroctively back to date } \\
\text { of loss of work }\end{array}$
\end{tabular} & $\begin{array}{l}\text { Waiting period } \\
\text { Length of waiting period } \\
\text { (for which benefit is not } \\
\text { paid at start of claim), if any }\end{array}$ & $\begin{array}{l}\text { Application routes } \\
\text { Possible application } \\
\text { routes: in person (P), } \\
\text { telephone (T), fax (F), } \\
\text { post (W), e-mail (E), or } \\
\text { online (O) }\end{array}$ & $\begin{array}{l}\text { Share of claimants } \\
\text { registering online }\end{array}$ & \begin{tabular}{l}
\multicolumn{1}{c}{ Delay } \\
Delay until first contact \\
with job-placement \\
services
\end{tabular} \\
\hline Spain & $A, R$ & 1 & $P, W, T, O^{f)}$ & .. & $\begin{array}{l}15 \text { days after cessation } \\
\text { of work }\end{array}$ \\
\hline Sweden & $S, R$ & 7 days & $\mathrm{P}, \mathrm{T}, \mathrm{O}^{\mathrm{g})}$ & $37 \%$ & $\begin{array}{l}\text { No enforced limit, but } \\
\text { usually within } 5 \text { days }\end{array}$ \\
\hline Switzerland & $S$ or $A$ & 5 days & $P, W$ & $x$ & $\begin{array}{l}\text { Immediately (first day } \\
\text { claimant desires to } \\
\text { receive benefits) }\end{array}$ \\
\hline Turkey & $A, R$ & 1 & $\mathrm{P}, \mathrm{O}$ & $21 \%$ & $\begin{array}{l}\text { Not applicable, direct } \\
\text { visits not required }\end{array}$ \\
\hline United Kingdom & s & 7 days & $\mathrm{P}, \mathrm{W}, \mathrm{T}, \mathrm{O}$ & .. & Not applicable \\
\hline United States & B or S & 7 days (most states) & $P, W, T, O^{h)}$ & $63 \%$ & $\begin{array}{l}\text { No enforced maximum } \\
\text { delay }\end{array}$ \\
\hline
\end{tabular}

Notes to Table 3.1:

a) Applications for benefit must be made in person; PES registration is possible in person, by telephone or online.

b) Applications can be made by phone in special situations.

c) Registration with the TE-offices: in person or online; Unemployment benefits: mail or online.

d) Since the end of 2015, all registrations are made online. Prospective claimants can, however, use free personal computers at the PES (Pôle Emploi) and, if necessary, receive help from PES employees via telephone or directly at the PES.

e) The status of unemployed is a mandatory prerequisite prior to application for the benefit and an inperson a visit at the SEA is required to establish the status. The subsequent benefit application may be i) submitted at the local office of State Social insurance agency (SSIA) (approx.50-60\%); ii) submitted at the local office of SEA by applying for the status of unemployed (if social insurance period is from 1996) (approx.40\%); iii) sent in electronic form (using electronic signatures); iv) sent by post.

f) Registration has to be done in person, but claimants can also apply for unemployment benefits online. In certain cases, applications can be made by phone, but only in cases like the renewal of the benefit after a period of work under certain circumstances. In exceptional cases, applications can be made by mail.

g) The Swedish PES also offers the option of PES registrations in unmanned PES offices via video link. h) A small number of claimants (less than 1\%) may also apply for unemployment benefits through their employer.

\subsection{Benefit sanction provisions}

55. Figure 8 ranks the severity of legal rules regarding benefit sanctions that are to be applied when benefit claimants fail to comply with any of the above-listed availability- and job-search requirements. Sanction provisions tend to be strictest in Southern and Eastern Europe as well as in Chile and Turkey, while they are more lenient in Central and Northern Europe as well as in the two East Asian countries (Japan and Korea). High scores typically reflect a strong and immediate link between benefits and compliance with all relevant conditions. For instance, quitting a job voluntarily or a single refusal of a suitable job offer of work can, in these cases, lead to a complete loss of benefits. 
Figure 8. Strictness of benefit sanction provisions, 2017

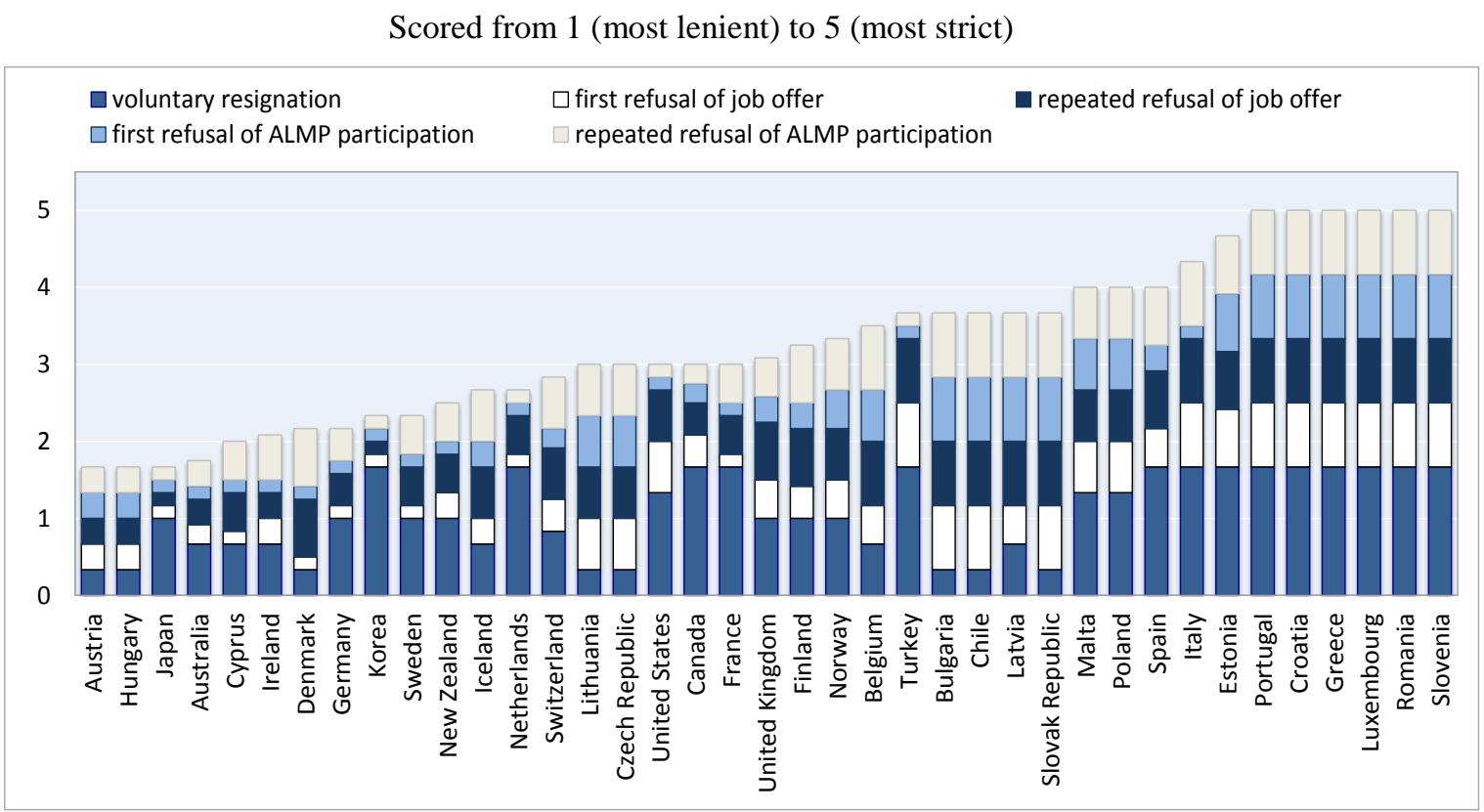

\subsubsection{Item 7: Sanctions for voluntary resignation from employment}

56. In Spain, Slovenia and Romania, claimants who are judged to have terminated their employment contract voluntarily do not qualify for unemployment benefits at all. Belgium can in principle impose long-lasting suspension of benefits of up to one year (though this is not always applied in practice). In contrast, in Austria or Denmark voluntary resignation from employment is sanctioned with a comparatively lenient temporary disqualification lasting 4 and 3 weeks, respectively. Voluntary resignations do not result in any sanction in Chile, Lithuania or the Slovak Republic. Hungary introduced a mild sanction for voluntary resignations in 2016: Claimants who quit their jobs voluntarily cannot participate in public employment ("public works") programmes.

57. Most countries specify a number of reasons for voluntary resignations that do not result in a sanction (see Annex). However, countries may not list particular reasons as valid simply because they see the validity of these reasons as self-evident (for instance, in the case of health-related reasons or harassment and discrimination at the workplace).

58. Belgium, Germany, Denmark, New Zealand, Sweden, or Switzerland explicitly specify a large number of valid reasons for voluntary resignation, while other European countries tend to be particularly strict in this regard. Bulgaria, Estonia, Italy, Malta, Romania, and Slovenia list two reasons, while Spain and Poland list three. France lists only one reason as valid, while Greece and Latvia do not specify any reason at all. Lithuania does not sanction voluntary 
unemployment at all (though job loss due to misconduct triggers a significantly longer waiting period of three months).

59. No explicit lists of reasons exist in countries where voluntary resignation from employment is not penalised (Chile or the Slovak Republic) or where only very mild sanctions are imposed (Hungary). The United Kingdom leaves the decision of whether resignations were reasonable or not to the courts.

\subsubsection{Item 8: Sanctions for refusals of suitable employment}

60. Sanctions for an initial refusal of a suitable job range typically between a complete disqualification from benefits to temporary and/or partial disqualification lasting a few weeks. In Croatia, Greece, and Italy, workers who qualify for benefits but then refuse a job offer become ineligible. Belgium can apply a sanction of up to one year (similar to Item 7). A first refusal results in a disqualification for 1 week in Sweden, 2 weeks in Korea, 8 weeks in Australia, for 3 months in Spain and for 13 weeks in the United Kingdom and New Zealand In the Netherlands, a variable reduction in payments - which can be very small, but can also amount to 100 per cent - is imposed. It can be useful to read these sanction provisions in conjunction with the information on job-search documentation requirements presented above (Item 6).

\subsubsection{Item 9: Sanctions for repeated refusals of suitable employment}

61. Where a first refusal of a suitable job does not result in an immediate disqualification from benefits, repeated refusals of offers of suitable jobs tend to be penalised more harshly than initial refusals. In Sweden, for instance, where the initial sanction is a comparatively lenient disqualification for one week, subsequent refusals result in disqualifications for two weeks and then nine weeks. A fourth refusal will result in a complete disqualification from benefits. Particularly steep is the increase in the United Kingdom, where sanctions increase from 13 to 26 weeks between the first and second refusal and finally up to 156 weeks (three years) for a third refusal.

\subsubsection{Item 10: Sanctions for refusals to participate in ALMPS}

62. Sanctions for refusals to participate in ALMPs tend to be either equally strict or moderately more lenient than those for refusals of work. In Australia, for instance, claimants who miss appointments or commit similar failures have their benefit payments suspended and are given a re-connection requirement. Benefit payments resume if claimants comply with their reconnection requirement. A refusal of an offer of employment, however, is considered a "serious failure" and results in a disqualification for 8 weeks (see also above). In Germany or Austria, the same sanctions as for refusals of work are applied.

\subsubsection{Item 11: Sanctions for repeated refusals to participate in ALMPS}

63. As is the case with sanctions for refusals of employment, repeated refusals tend to be penalised more harshly than initial ones. In Spain, a second refusal is punished with a disqualification for 6 months and the third one with a complete disqualification. In Switzerland, subsequent refusals of offered ALMP 
participation may be taken as a signal that the jobseeker in question is not really available for employment. In the Czech Republic, on the other hand, jobseekers are always disqualified for six months every time they refuse an offer to participate in an ALMP.

64. Several countries have changed their sanctioning rules since 2014.

- Norway raised the sanction for voluntary resignations from employment or a refusal of an offer of employment or to participate in ALMPs from eight to twelve weeks. The sanctions for a second refusal of suitable employment or ALMP participation were also lifted from twelve to 26 weeks.

- In Hungary, claimants who resign from jobs voluntarily may not participate in an employment programme for the first 90 days of their unemployment spell. Before, no sanction for voluntary resignations was in place.

- Finland changed some aspects of its sanctioning rules. While a refusal of an offer of employment that comes from the PES or a failure to apply for a suggested vacancy still result in a disqualification for 60 days, a refusal of a job that was already offered by the prospective employer is sanctioned with a disqualification for 90 days. A previous rule, introduced in 2014, that jobseekers who were sanctioned during the first 250 days would also receive reduced benefits during the last 100 days of their overall entitlement period was abolished.

- Italy introduced significant changes to its sanctioning rules in 2015. A refusal of an offer of employment is now sanctioned with a complete disqualification from benefits instead of a temporary disqualification for four months. Failures to attend meetings or to participate in ALMPs are penalised more leniently now with reductions of benefit payments.

65. Romania provided some clarifications concerning its sanctioning rules. A failure to accept an offer of suitable work or to participate in an ALMP results in a complete disqualification from benefit receipt. Benefits cannot, other than reported in 2014, be reinstated after 60 days. This rule has been in place in 2014 already and still is in place. 


\section{Eligibility conditions for lower-tier benefit programmes}

66. The 2017 questionnaire collected, for the first time, data on the strictness of eligibility criteria for lower-tier benefit programmes alongside the data on the main unemployment benefit programme presented above. The response rate to the questionnaires on lower-tier benefits was considerably lower: no responses were received from three countries; in thirteen cases, some information was missing. In some cases, this may be because many requirements and conditions that are imposed on claimants of $1^{\text {st }}$-tier benefits do not exist in similar form for lower-tier benefits, or because these rules are not clearly defined in official statutes. For instance, a number of lower-tier programmes operate at regional or local level, or they may be designed to cover a more heterogeneous population than $1^{\text {st }}$-tier benefits. As a result, authorities or caseworkers may be given greater leeway in determining how best to balance adequate support with concerns over ensuring incentives and claimant responsibilities for regaining self-sufficiency.

67. All countries covered in this study received at least one additional questionnaire. A few countries operate more than one lower-tier programme (typically unemployment assistance and social assistance) and were accordingly sent two additional questionnaires (Austria, France, Chile, Croatia, Estonia, Finland, Greece, Hungary, Iceland, Ireland, Portugal, Japan, Sweden, Switzerland). Table 4 lists all benefit programmes that were included in the questionnaire.

68. Countries' questionnaire responses were coded and aggregated in the same way as the data on $1^{\text {st }}$-tier programmes. However, aggregate scores were only computed in cases where information on all items was provided. 26 out of 39 countries can currently be compared using the aggregate indicators for the first lower-tier benefit. Future updates will seek to complete responses from countries that are currently missing.

69. This short summary focuses on the main differences of eligibility criteria between $1^{\text {st }}$-tier and lower-tier benefits, and highlights salient features of eligibility rules for lower-tier benefits in selected countries. The Annex papers the complete set of responses, including for countries with missing items, which were not included in the scoring exercise.

70. A fundamental difference between $1^{\text {st }}$-tier and lower-tier programmes is that the latter do not always require claimants to be available for employment as not all claimants of assistance benefits may in fact be expected to take up employment. Some may be unable to work, or have an illness or impairment that limits their employability. For others, social integration or rehabilitation may be a more immediate priority than (or a pre-requisite for) employment (Immervoll, 2012). Questionnaire responses show, however, that a clear majority of 25 countries requires lower-tier claimants to be available for employment. Five 
countries, Australia, New Zealand, Norway, Romania, and Turkey, have only a partial requirement to be available for work (e.g., because those lower-tier claimants who are able to work may be referred directly to the $1^{\text {st }}$-tier benefit, as in Australia).

71. Four countries responded that lower-tier claimants are not required to be available for employment (Chile, Luxembourg, Poland, and the Slovak Republic). The social assistance programme in Chile is aimed at those in extreme poverty and is not directly comparable to minimum-income programmes operating in other OECD countries. The programme in Luxembourg foresees a possibility to impose a requirement to be available for employment if deemed reasonable, but a general requirement was explicitly negated. In Poland and the Slovak Republic, claimants of lower-tier benefits can be required to participate in activation programmes or accept available jobs in some circumstances, but a general requirement does not exist.

72. Lower-tier programmes with a requirement to be available for employment can be grouped as follows. First, there are programmes that are aimed at jobseekers who are capable to work but who do not (or no longer) qualify for $1^{\text {st }}$-tier benefits and lower-tier programmes may be largely or entirely separate from a legal point of view in these cases. The German Arbeitslosengeld II is one example. Second, there are lower-tier programmes that are institutionally closely integrated with the $1^{\text {st }}$-tier programme, and whose formal eligibility rules are often largely identical. An example is the UK's Jobseeker's Allowance, which is split into an earnings-related ("contribution-based", $1^{\text {st }}$-tier) and a means-tested lower-tier programme. Other examples are the Finnish and Swedish programmes, that include both a voluntary (earnings-related, $1^{\text {st }}$-tier) and a basic lower-tier benefit. 
Table 4. Scope of the eligibility questionnaires: $1^{\text {st }}$ - tier and lower-tier benefit programmes

\begin{tabular}{|c|c|c|c|}
\hline Country & Tier-1 & First lower-tier & Second lower-tier \\
\hline Australia & Newstart Allowance & Special Benefit & \\
\hline Austria & Arbeitslosengeld & Notstandshilfe & Bedarfsorientierte Mindestsicherung \\
\hline Belgium & Assurance chômage & Aide Sociale & \\
\hline Bulgaria & Unemployment Insurance & Social Assistance & \\
\hline Canada & Employment Insurance & Ontario Works & \\
\hline Chile & Unemployment Insurance & Chile Solidario & Unemployment Subsidy \\
\hline Croatia & Unemployment Insurance & Social Welfare & Cash Allowance \\
\hline Cyprus & Unemployment Insurance & Guaruanteed Minimum Income (GMI) & \\
\hline Czech Republic & Unemployment Benefit & Assistance in Material Need & \\
\hline Denmark & Unemployment Insurance & Social Assistance & \\
\hline Estonia & Primary Unemployment Insurance & Secondary Unemployment Allowance & Subsistence Benefit \\
\hline Finland & Unemployment Insurance and Basic Allowance & Labour Market Subsidy & Social Assistance \\
\hline France & Unemployment Insurance (ARE) & Unemployment Assistance (ASS) & Social Assistance (RSA) \\
\hline Germany & Arbeitslosengeld (ALG I) & Grundsicherung für Arbeitslose (ALG II) & \\
\hline Greece & Unemployment Insurance & Special Aid & Long-term Unemployment Benefit \\
\hline Hungary & Unemployment Insurance & Jobseeker's Allowance (pre-pension) & Employment-Substituting Support (ESS) \\
\hline Iceland & Unemployment Insurance & Unemployment Assistance & Social Assistance \\
\hline Ireland & Jobseeker's Benefit & Jobseeker's Allowance & $\begin{array}{l}\text { Basic Supplementary Welfare Allowance } \\
\text { (SWA) }\end{array}$ \\
\hline Israel & Unemployment Insurance & Income Support & \\
\hline Italy & $\begin{array}{l}\text { New Social Insurance Provision for } \\
\text { Unemployment (NASpl) }\end{array}$ & Assegno di Disoccupazione (ASDI) & \\
\hline Japan & Employment Insurance & $\begin{array}{l}\text { Public Assistance (Support System for Job } \\
\text { Seekers) }\end{array}$ & $\begin{array}{l}\text { Public Assistance (Sekatsu-hogo - Social } \\
\text { Assistance) }\end{array}$ \\
\hline Korea & Job-Seeking Allowance & National Basic Livelihood Security & \\
\hline Latvia & Unemployment Insurance & Guaruanteed Minimum Income & \\
\hline Lithuania & Unemployment Insurance & Social Assistance Benefit & \\
\hline Luxembourg & Unemployment Insurance & Guaruanteed Minimum Income & \\
\hline Malta & Unemployment Insurance & Unemployment Assistance & Social Assistance \\
\hline Netherlands & Unemployment Benefit (WW-uitkering) & Participatiewet & \\
\hline New Zealand & Jobseeker Support & Emergency Benefit & \\
\hline Norway & Unemployment Insurance & Social Economic Assistance (SEA) & \\
\hline Poland & Unemployment Insurance & Social Assistance & \\
\hline Portugal & Unemployment Insurance & Unemployment Social Allowance (USA) & Social Insertion Income (SII) \\
\hline Romania & Unemployment Insurance & Social Assistance (GMI) & \\
\hline Slovak Republic & Unemployment Insurance & Social Assistance & \\
\hline Slovenia & Unemployment Insurance & Financial Social Assistance & \\
\hline Spain & Unemployment Insurance & Unemployment Assistance & Renta Minima de Inserción \\
\hline Sweden & Income-related Unemployment Insurance & Basic Unemployment Insurance & Social Welfare Allowance \\
\hline Switzerland & Assurance chômage & Assistance chômage & Aide Sociale \\
\hline Turkey & Unemployment Insurance & Social Assistance & \\
\hline United Kingdom & Jobseekers Allowance (Contribution-Based) & Jobseekers Allowance (Income-Based) & \\
\hline United States & Unemployment Insurance & $\begin{array}{l}\text { Temporary Assistance for Needy Families } \\
\text { (TANF) }\end{array}$ & \\
\hline
\end{tabular}


73. Figure 9 presents overall strictness scores, as well as sub-scores for availability criteria, job-search requirements and sanctions for $1^{\text {st }}$-tier and lowertier programmes for those programmes for which countries provided complete responses. Eligibility conditions for lower-tier programmes are neither more nor less strict than for $1^{\text {st }}$-tier programmes in any general sense:

- In many countries, availability and job-search requirements are largely or entirely identical. This includes Australia, Finland, Italy, Latvia, Malta, New Zealand, Sweden, and the United Kingdom. Where differences do exist between programmes, availability conditions are generally tighter for claimants of lower-tier benefits. For instance, in eight countries claimants of $1^{\text {st }}$-tier benefits do not have to be available for work in occupations that differ from their previous work, or only to a limited extent. By contrast, no country permits claimants of lower-tier benefits to indefinitely restrict availability to their own occupation. And there are only two countries where claimants can do so for an initial period of time (one year in Spain and, de-facto, three months in Slovenia). Twelve countries expect lowertier claimants to be fully occupationally mobile from the start. Denmark is the only country where availability criteria for $1^{\text {st }}$-tier claimants were coded as more restrictive than for lower-tier claimants. ${ }^{4}$ In Germany, there is little difference in terms of job-search requirements, yet lower-tier (Arbeitslosengeld II) claimants are subject to stricter availability criteria. The same is the case in Austria. In the Netherlands, job-search and monitoring requirements are tighter for $1^{\text {st }}$-tier ( $W W$ uitkering) benefits than for the recently introduced lower-tier programme (Participatiewet).

- However sanction rules are often considerably more lenient in lower-tier benefits. In Germany, for instance, sanctions for $1^{\text {st }}$-tier benefit claimants take the form of temporary disqualifications, whereas lower-tier claimants have their benefit payments reduced (unless they repeatedly fail to comply). Estonia, Ireland, Japan and Romania are further examples of such a pattern. Less strict sanction rules for claimants of lower-tier benefits may, in part, reflect a concern about the risk of extreme hardship if benefit payments were discontinued or reduced for a group that may have no or very limited access to alternative income sources (Immervoll, 2012). However, lenient rules in lower-tier programmes may also reflect the difficulties of prescribing precise rules for a very heterogeneous claimant population, and a desire to give the (often local) authorities more leeway in designing customised solutions for different types of claimant (see e.g. Buiskol et al., 2015).

4. Danish unemployment insurance claimants are required to be both available for and actively seeking work while participating in ALMPs, while social assistance claimants need to be available for but not actively seeking work. 
gure 9. Strictness of eligibility criteria compared across benefit programmes, 2017

Scored from 1 (most lenient) to 5 (most strict)

Panel A. Overall strictness

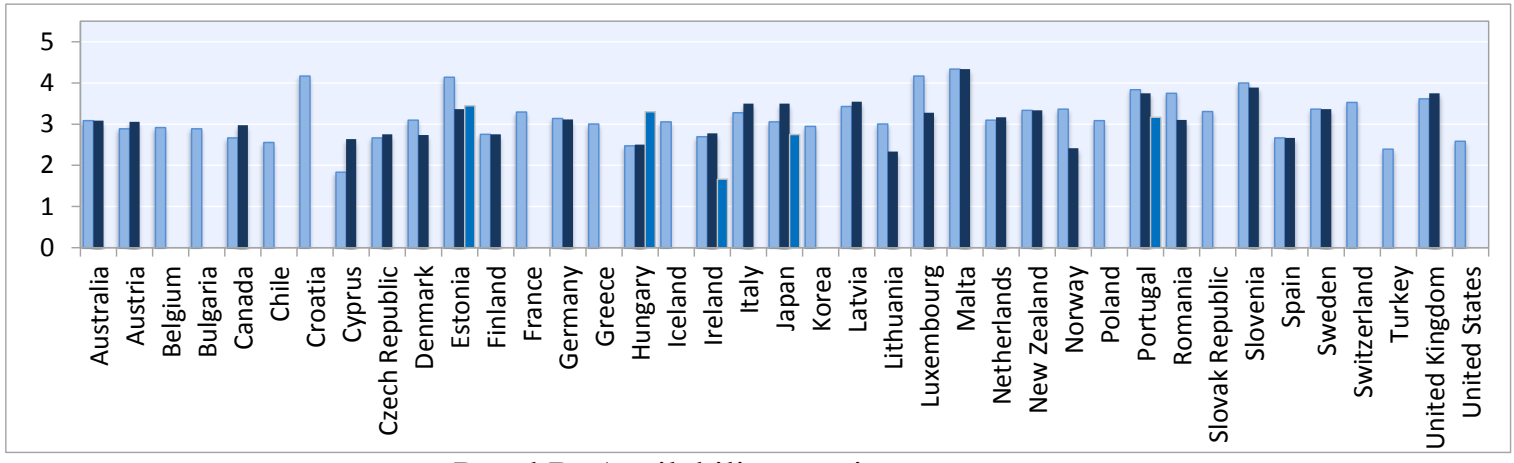

Panel B. Availability requirements

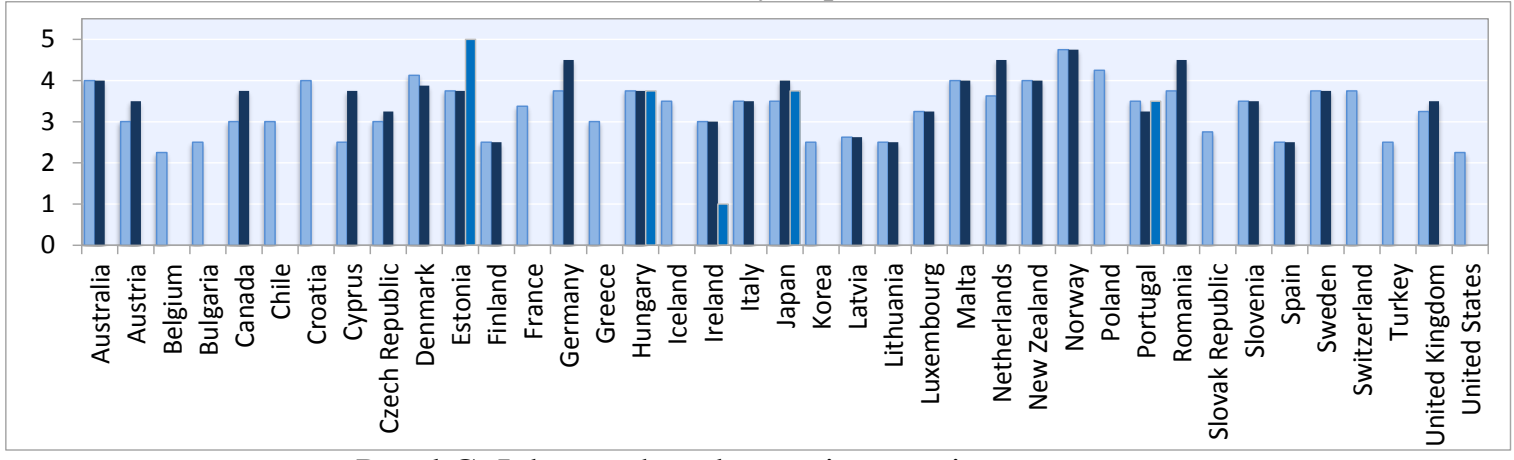

Panel C. Job-search and reporting requirements

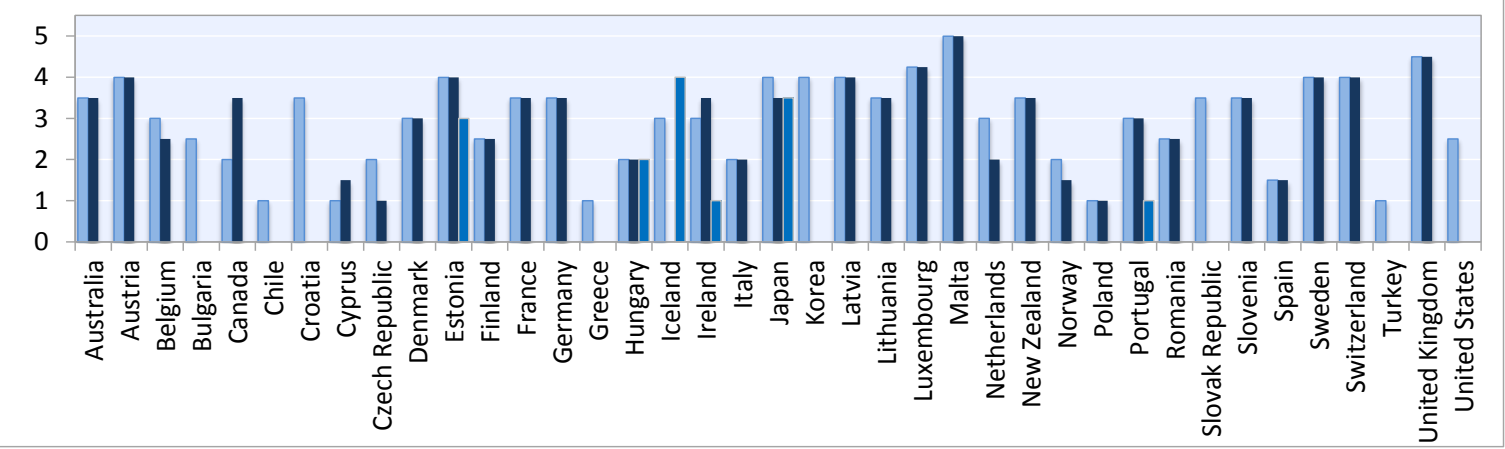

Panel D. Benefit sanction provisions

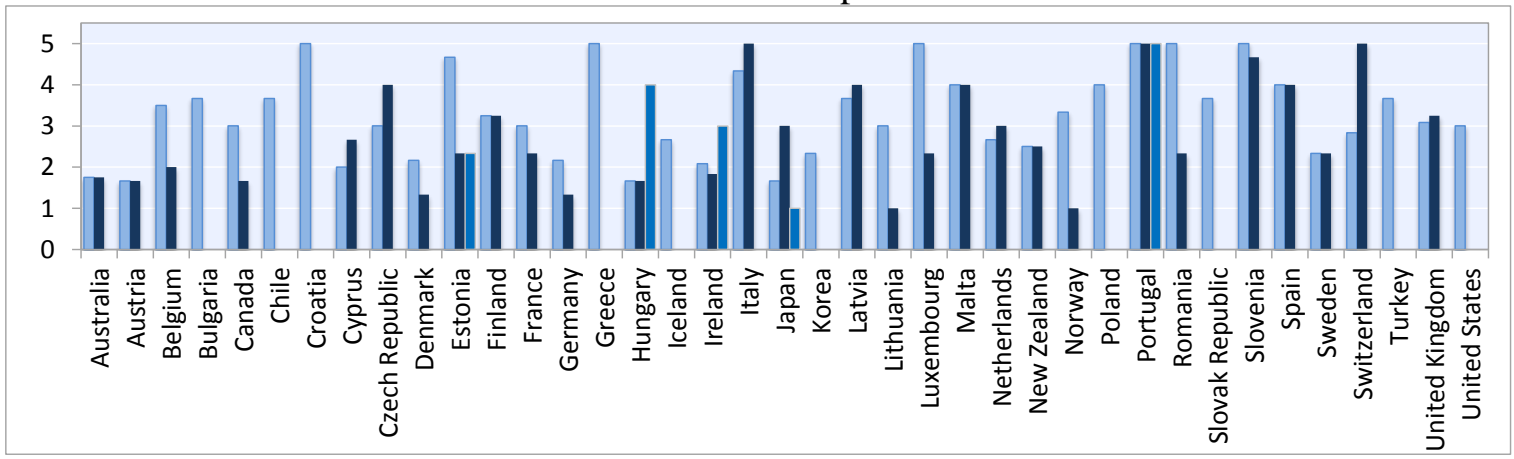

$\square$ Tier-1

- First lower-tier

n Second lower-tier

HOW DEMANDING ARE ACTIVATION REQUIREMENTS FOR JOBSEEKERS?

For Official Use 


\section{Conclusions}

74. This paper presents updated and extended results on activity-related eligibility criteria for unemployment and related out-of-work benefits in OECDand EU-countries, comparing the strictness of "demanding" elements built into unemployment benefits across countries and over time. Eligibility criteria for unemployment benefits determine what claimants need to do in order to successfully claim benefits. In most OECD- and EU countries, benefit systems feature specific rules that define the job offers that claimants need to accept, requirements to paper on the outcomes of independent job-search efforts, the obligation to participate in active labour market programmes (ALMPs), as well as sanctions for non-compliance with these rules.

75. Such provisions generally aim to strengthen incentives to look for, prepare for, and accept employment. They may also be used as a targeting device to reduce demands on benefit systems and employment services, by limiting support to "genuine" or "deserving" jobseekers. Available meta-evaluations suggest that programmes featuring job-search monitoring and sanctions indeed yield positive employment effects. At the same time, overly demanding eligibility criteria can exclude some intended recipients from financial support and the employment services associated with them.

76. Results in this paper document a large number of reforms enacted after the Great Recession and suggest a slight convergence of policy rules across countries. However, overall measures of the strictness of eligibility criteria have remained relatively unchanged during the recent past. Overall strictness measures for lower-tier programmes are often similar to $1^{\text {st }}$-tier benefits. But results suggest that they commonly differ in two respects: Availability requirements tend to be stricter for lower-tier claimants, while sanction rules tend to be tougher for $1^{\text {st }}$-tier programmes.

77. Complementing existing policy indicators on benefit generosity and financial work incentives, the present results and the emerging long time series on eligibility strictness scores is intended to facilitate policy monitoring and benchmarking of countries' rights and responsibilities approaches for jobseekers. It also aims to inform debates on the policy and non-policy drivers of trends in benefit coverage (OECD, 2018b). Merging existing historical policy data with recent and future OECD-Secretariat compilations of eligibility conditions, as illustrated in Box 2.1, holds the prospect of supporting analytical and econometric uses of the strictness indicators. Such future work could complement country-specific studies of the effects of eligibility strictness on employment outcomes. It could also enable explorations of the political economy behind policy initiatives that make benefits more or less readily available, such as whether and when changing labour-market conditions are associated with attempts to tighten access to income support. 


\subsection{References}

ABBRING, J.H., VAN DEN BERG, G.J. \& VAN OURS, J.C. 2005. The effect of unemployment insurance sanctions on the transition rate from unemployment to employment. The Economic Journal, 115, 602-30.

ACEMOGLU, D. \& SHIMER, R. 2000. Productivity gains from unemployment insurance. European Economic Review, 44, 1195-1224.

ARULAMPALAM,W. 2001. Is Unemployment Really Scarring? Effects of Unemployment Experiences on Wages, Economic Journal, Vol. 111, 585-606.

ARNI, P., LALIVE, R. \& VAN OURS, J. C. 2013. How effective are unemployment benefit sanctions? Looking beyond unemployment exit. Journal of Applied Econometrics, 28, 1153-1178.

ATKINSON, A.B. \& MICKLEWRIGHT, J., 1991. Unemployment compensation and labor market transitions: a critical review. Journal of economic literature, 29(4), pp.16791727.

BELL, D.N.F. \& BLANCHFLOWER, D.G. 2009. What Should Be Done About Rising Unemployment in the OECD?, IZA Discussion Paper, No. 4455, Institute for the Study of Labor, Bonn.

VAN DEN BERG, G. \& VAN DER KLAAUW, B. 2006. Counselling and monitoring of unemployed workers: Theory and evidence from a controlled social experiment. International Economic Review, 47, 895-936.

VAN DEN BERG, G., VAN DER KLAAUW, B. \& VAN OURS, J. C. 2004. Punitive Sanctions and the Transition Rate from Welfare to Work. Journal of Labor Economics, 22, 211-241.

VAN DEN BERG, G. \& VIKSTRÖM, J. 2014. Monitoring Job Offer Decisions, Punishments, Exit to Work, and Job Quality. Scandinavian Journal of Economics, 116, 284-334.

BLACK, D. A., SMITH, J. A., BERGER, M. C. \& NOEL, B. J. 2003. Is the Threat of Reemployment Services More Effective than the Services Themselves? Evidence from Random Assignment in the UI System. The American Economic Review, 93, 13131327.

BOOCKMANN, B., Thomsen, S.L. \& Walter, T., 2014. Intensifying the use of benefit sanctions: an effective tool to increase employment?. IZA Journal of Labor Policy, $3(1)$, p.21.

BORJAS, G. J. 2010. Labor Economics, New York, McGraw-Hill.

BORLAND, J. \& TSENG, Y.P., 2007. Does a minimum job search requirement reduce time on unemployment payments? Evidence from the jobseeker diary in Australia. Industrial and Labor Relations Review, 60(3), pp.357-378. 
BUISKOL, B.-J., BROEK, S. \& DENTE, G. 2015. The Social and Employment Situation in the Netherlands and Outlook on the Dutch EU Presidency 2016. European Parliament, Policy Department A: Employment and Social Affairs Briefing. Brussels.

CARD, D., KLUVE, J. \& WEBER, A. 2010. Active labour market policy evaluations: A meta-analysis", The Economic Journal, 120, F452-F477.

CARD, D., KLUVE, J. \& WEBER, A. 2015. What works? A meta analysis of recent active labor market program, evaluations, NBER Working Papers, No. 21431, National Bureau of Economic Research.

CAUSA, O. \&HERMANSEN, M. 2017. Income redistribution through taxes and transfers across OECD countries, OECD Economics Department Working Paper, forthcoming.

CLASEN, J. \& CLEGG, D. 2007. Levels and levers of conditionality: measuring change within welfare states. In: CLASEN, J. \& SIEGEL, N. A. (eds.) Investigating Welfare State Change - The 'Dependent Variable Problem' in Comparative Analysis. Cheltenham: Edwar Elgar.

ELLWOOD, D.T. 1982. Teenage Unemployment: Permanent Scars or Temporary Blemishes?, in R.B. FREEMAN \& WISE, D.A. (eds.), The Youth Labor Market Problem: Its Nature, Causes, and Consequences. University of Chicago Press and National Bureau of Economic Research.

ESSER, I., FERRARINI, T., NELSON, K., PALME, J. \& SJÖBERG, O. 2013. Unemployment benefits in EU member states. European Commission, DirectorateGeneral for Employment, Social Affairs and Inclusion.

ESTÉVEZ-ABE, M., IVERSEN, T. \& SOSKICE, D. 2001. Social Protection and the Formation of Skills: A Reinterpretation of the Welfare State. In: HALL, P. A. \& SOSKICE, D. (eds.) Varieties of Capitalism: The Institutional Foundations of Comparative Advantage. Oxford: Oxford University Press.

FREDRIKSSON, P. \& HOLMLUND, B. 2006. Improving incentives in unemployment insurance: A review of recent research. Journal of Economic Surveys, 20, 357-386.

FRYER, D. 1986. Employment deprivation and personal agency during unemployment: A critical discussion of Jahoda's explanation of the psychological effects of unemployment. Social Behavior, 1, 3-23.

GALLIE, D. \& PAUGAM, S. 2000. Welfare regimes and the experience of unemployment in Europe, Oxford, Oxford University Press.

GREGG, P. \& TOMINEY, E. 2005. The Wage Scar from Male Youth Unemployment. Labour Economics, 12, 487-509.

GRAETZ, B. 1993. Health Consequences of Employment and Unemployment: Longitudinal Evidence for Young Men and Women. Social Science $\backslash \&$ Medicine, 36, 715-724.

GRAVERSEN, B.K. \& VAN OURS, J.C., 2008. Activating unemployed workers works; Experimental evidence from Denmark. Economics Letters, 100(2), pp.308-310. 
GRIGGS, J. \& EVANS, M., 2010. Sanctions within conditional benefit systems: A review of evidence. Joseph Roundtree Foundation.

GRUBB, D. 2000. Eligibility criteria for unemployment benefits. OECD Economic Studies, $31,147-184$.

HASSELPFLUG, S. (2005). Availability criteria in 25 countries. Ministry of Finance Denmark Working Paper, 12/2005.

HUMMEL-LILJEGREN, H. 1981. Zumutbare Arbeit: Das Grundrecht der Arbeitslosen, Berlin, Duncker \& Humblot.

IMMERVOLL, H, 2012, "Minimum-Income Benefits in OECD Countries: Policy Design, Effectiveness and Challenges", in: :D. J. Besharov and K. A. Couch (eds.), Counting the Poor. New Thinking About European Poverty Measures and Lessons for the United States, Oxford University Press, 171-209.

IMMERVOLL, H. \& O'DONOGHUE, C. 2001. What Difference Does a Job Make? The Income Consequences of Joblessness in Europe, In: GALLIE, D. (ed.), Resisting Marginalisation: Unemployment Experience and Social Policy in the European Union, Oxford: Oxford University Press.

IMMERVOLL, H. \& RICHARDSON, L. 2011. Redistribution policy and inequality reduction in OECD countries: What has changed in two decades? LIS Working Paper Series. Luxembourg.

JAHODA, M. 1982. Employment and Unemployment: A Social-Psychological Analysis. Cambridge: Cambridge University Press.

KALIL, A., SEEFELDT, K. S. \& WANG, H.-C. 2002. Sanctions and Material Hardship under TANF. Social Service Review, 76, 643-662.

KLEPINGER, D.H., JOHNSON, T.R. \& JOESCH, J.M., 2002. Effects of unemployment insurance work-search requirements: The Maryland experiment. Industrial and Labor Relations Review, 56(1), pp.3-22.

KLETZER, L.G. \& FAIRLIE, R.W. 2003. The Long-Term Costs of Job Displacement for Young Adult Workers, Industrial and Labor Relations Review, 56, 682-698.

KLUVE, J. 2010. The Effectiveness of European Active Labour Market Programs”, Labour Economics, 17, 904-918.

KNOTZ, C. forthcoming. A Rising Workfare State? Unemployment Benefit Conditionality in 21 OECD Countries, 1980-2012. Journal of International and Comparative Social Policy, https://doi.org/10.1080/21699763.2018.1472136

KNOTZ, C. \& NELSON, M. 2015. The Comparative Unemployment Benefit Conditions and Sanctions Dataset (v. 03/2015). Department of Political Science, Lund University, Lund. 
LALIVE, R., ZWEIMÜLLER, J. \& VAN OURS, J. C. 2005. The Effect of Benefit Sanctions on the Duration of Unemployment. Journal of the European Economic Association, 3, 1386-1417.

LANGENBUCHER, K. 2015. "How demanding are eligibility criteria for unemployment benefits, quantitative indicators for OECD and EU countries." OECD Social, Employment and Migration Working Papers, 166.

LAYARD, R., NICKELL, S. \& JACKMAN, R. 2005. Unemployment: Macroeconomic Performance and the Labour Market, Oxford, Oxford University Press.

LE BARBANCHON, T., 2016. The effect of the potential duration of unemployment benefits on unemployment exits to work and match quality in France. Labour Economics, 42, pp.16-29.

LEE, B. J., SLACK, K. S. \& LEWIS, D. A. 2004. Are Welfare Sanctions Working as Intended? Welfare Receipt, Work Activity, and Material Hardship among TANFRecipient Families. Social Service Review, 78, 370-403.

MCVICAR, D., 2008. Job search monitoring intensity, unemployment exit and job entry: Quasi-experimental evidence from the UK. Labour Economics, 15(6), pp.1451-1468.

MINISTRY OF FINANCE 1998. Availability Criteria in selected OECD countries. Ministry of Finance Denmark Working Paper, 06/1998.

MROZ, T.A. \& SAVAGE, T.H. 2006. The Long-term Effects of Youth Unemployment. Journal of Human Resources, 41, 259-293.

OECD 1994. The OECD Jobs Study: facts, analysis, strategies. Paris, OECD Publishing

OECD 2005. Employment Outlook. Paris, OECD Publishing

OECD 2006. Employment Outlook 2006. Boosting Jobs and Incomes. Paris, OECD Publishing

OECD 2007. Benefit and Wages. OECD Indicators. Paris, OECD Publishing

OECD 2008a. Are All Jobs Good for Your Health? The Impact of Work Status and Working Conditions on Mental Health. OECD Employment Outlook 2008, 203-240, http://dx.doi.org/10.1787/empl_outlook-2008-6-en.

OECD 2011. Divided We Stand: Why Inequality Keeps Rising, Paris, OECD Publishing.

OECD 2015. Employment Outlook, Paris, OECD Publishing.

OECD 2014. Connecting People with Jobs: Activation Policies in the United Kingdom, Paris, OECD Publishing.

OECD 2016. Society at a Glance: OECD Social Indicators, Paris, OECD Publishing. 
OECD 2017. Basic income as a policy option: Can it add up?, Policy Brief on the Future of Work. Paris: OECD Publishing, https://www.oecd.org/els/emp/Basic-Income-PolicyOption-2017.pdf.

OECD 2018a. The Future of Social Protection, Policy Brief on the Future of Work. Paris: OECD Publishing, https://www.oecd.org/els/emp/Basic-Income-Policy-Option2017.pdf.

OECD 2018b. "Benefit coverage", OECD Employment Outlook, Paris: OECD Publishing, forthcoming.

OREOPOULOS, P., VON WACHTER, T. \& HEISZ, A. 2012. The Short- and Long-Term Career Effects of Graduating in a Recession. American Economic Journal: Applied Economics, 4, 1-29.

OSCHMIANSKY, F., SCHMID, G. \& KULL, S. 2003. Faule Arbeitslose? Leviathan, 31, 331.

RØED, K. \& WESTLIE, L. 2012. Unemployment Insurance in Welfare States: The impacts of soft duration constraints. Journal of the European Economic Association, 10, 518554.

SALOMÄKI, A. \& MUNZI, T. 1999. Net replacement rates of the unemployed: Comparisons of various approaches", Economic Papers No. 133, Directorate-General for Economic and Financial Affairs, Commission of the European Communities.

SCHRAM, S. F., SOSS, J., FORDING, R. C. \& HOUSER, L. 2009. Deciding to Discipline: Race, Choice, and Punishment at the Frontlines of Welfare Reform. American Sociological Review, 74, 398-422.

SULLIVAN, D. \& VON WACHTER, T. 2009. Job Displacement and Mortality: An Analysis Using Administrative Data. Quarterly Journal of Economics, 124, 12651306.

SVARER, M. 2011. The Effect of Sanctions on Exit from Unemployment: Evidence from Denmark. Economica, 78, 751-778.

TATSIRAMOS, K. \& VAN OURS, J.C., 2014. Labor market effects of unemployment insurance design. Journal of Economic Surveys, 28(2), pp.284-311.

THOMAS, C., BENZEVAL, M. \& STANSFELD, S. A. 2004. Employment transitions and mental health: an analysis from the British household panel survey. Journal of Epidemiology and Community Health, 59, 243-249.

VENN, D. 2012. Eligibility Criteria for Unemployment Benefits: Quantitative Indicators for OECD and EU countries. OECD Social, Employment and Migration Working Papers, 131.

WU, C.-F., CANCIAN, M., MEYER, D. R. \& WALLACE, G. L. 2006. How Do Welfare Sanctions Work? Social Work Research, 30, 33-50. 
WULFGRAMM, M. 2014. Life satisfaction effects of unemployment in Europe: The moderating influence of labour market policy. Journal of European Social Policy, 24, 258-272. 